OPEN ACCESS

Edited by:

Lluis Tort,

Autonomous University of

Barcelona, Spain

Reviewed by:

Antonio Figueras,

Consejo Superior de Investigaciones

Cientificas (CSIC), Spain Luis Mercado,

Pontificia Universidad Católica de valparaíso, Chile

*Correspondence: Carolina Tafalla tafalla@inia.es

Specialty section:

This article was submitted to

Comparative Immunology,

a section of the journal

Frontiers in Immunology

Received: 21 November 2019

Accepted: 08 June 2020

Published: 09 July 2020

Citation:

Benedicenti O, Wang T, Morel E,

Secombes CJ, Soleto I,

Díaz-Rosales P and Tafalla C (2020)

Type I Interferon Regulates the

Survival and Functionality of $B$ Cells in

Rainbow Trout.

Front. Immunol. 11:1494.

doi: 10.3389/fimmu.2020.01494

\section{Type I Interferon Regulates the Survival and Functionality of B Cells in Rainbow Trout}

\author{
Ottavia Benedicenti ${ }^{1}$, Tiehui Wang ${ }^{2}$, Esther Morel ${ }^{1}$, Christopher J. Secombes ${ }^{2}$, \\ Irene Soleto ${ }^{1}$, Patricia Díaz-Rosales ${ }^{1}$ and Carolina Tafalla ${ }^{1 *}$ \\ ${ }^{1}$ Animal Health Research Center (CISA-INIA), Madrid, Spain, ${ }^{2}$ Scottish Fish Immunology Research Centre, School of \\ Biological Sciences, University of Aberdeen, Aberdeen, United Kingdom
}

Interferons (IFNs) orchestrate antiviral responses in jawed vertebrates and can be classified into three types based on different aspects of their genomic organization, structure and receptors through which they signal and function. Generally, type I and type III IFNs include cytokines that directly induce an antiviral response, whereas type II IFNs are well-known for their immunomodulatory role during viral infections. In mammals, type I IFNs have been shown to also regulate many aspects of B cell development and differentiation. Yet, these functions have been only faintly investigated for teleost IFNs. Thus, in the current study, we have examined the effects of a model type I rainbow trout IFN molecule (IFNa) on blood naive $\left(\mathrm{lgM}^{+} \mathrm{lgD}{ }^{+}\right)$B cells, comparing them to those exerted by type II IFN (IFN $\gamma)$. Our results demonstrate that IFNa increases the survival of naive rainbow trout $B$ cells, in the absence of lymphoproliferative effects, by rescuing them from spontaneous apoptosis. Additionally, IFNa increased the phagocytic capacity of blood $\mathrm{IgM}^{+} \operatorname{lgD}+\mathrm{B}$ cells and augmented the number of IgM-secreting cells in blood leukocyte cultures. IFN $\gamma$, on the other hand, had only minor effects up-regulating IgM secretion, whereas it increased the phagocytic capacity of $\operatorname{lgM}^{-}$cells in the cultures. Finally, given the recent identification of $9 m x$ genes in rainbow trout, we have also established which of these genes were transcriptionally regulated in blood naivve B cells in response to IFNa. This study points to a previously undescribed role for teleost type I IFNs in the regulation of $\mathrm{B}$ cell responses.

Keywords: teleost fish, B cells, interferon (IFN), IgM, phagocytosis

\section{INTRODUCTION}

Interferons (IFNs) are potent antiviral cytokines induced during the course of viral infections categorized into three classes (types I, II and III) on the basis of the receptors used, their genomic organization, sequence or structural homology (1). Although type I and type II IFNs were originally distinguished on the basis of the cells responsible for their production, it is now evident that they differ at many levels. Both types of cytokines are implicated in the response to viral infection, but while type I IFNs are well-known for their antiviral effects, type II IFNs play immunoregulatory functions during infection (2, 3). Thus, type I IFNs comprise a large family of closely related cytokines classified in mammals as IFN $\alpha, \operatorname{IFN} \beta, \operatorname{IFN} \varepsilon, \operatorname{IFN} \kappa, \operatorname{IFN} \omega, \operatorname{IFN} \delta, \operatorname{IFN} \zeta$, and $\operatorname{IFN} \tau(3,4)$. These cytokines are produced by almost every cell type upon the recognition of a virus or a virus -like 
stimulus. Once secreted, these IFNs bind to their cell surface receptor and initiate a signaling cascade that eventually leads to the transcriptional regulation of hundreds of IFN-stimulated genes (ISGs) [reviewed in (5)]. Among these type I IFN-induced proteins, many of them such as Myxovirus resistance $(\mathrm{Mx})$ proteins directly interfere with viral replication (6). On the other hand, IFN $\gamma$, the only type II IFN found in mammals, is secreted almost exclusively by $\mathrm{NK}$ and $\mathrm{T}$ lymphocytes in response to certain cytokines (7). IFN $\gamma$ has been shown to induce nitric oxide (NO) production, phagocytosis, and secretion of pro-inflammatory cytokines of macrophages, promoting their polarization to an M1 phenotype (8). IFN $\gamma$ also plays an important role in antigen presentation, as it increases MHC II expression and maturation of macrophages and dendritic cells (DCs) $(8,9)$. Interestingly, although only a limited subset of cells express IFN $\gamma$, its receptor is ubiquitously expressed, and through this interaction, IFN $\gamma$ is also capable of inducing antiviral effects similar to those elicited by type I IFNs (10). Mammalian type III IFNs, on the other hand, constitute a group of four cytokines that activate a signaling pathway similar to that of type I IFNs through a specific receptor $(11,12)$.

In addition to their direct antiviral effects, it has become evident in mammals that type I IFNs also play pleiotropic effects during the development and differentiation of $\mathrm{B}$ cells (13). In mice, for example, IFN $\alpha / \beta$ has been shown to increase the survival of $\mathrm{B}$ cells through a decrease of Fasmediated apoptosis $(14,15)$, and to enhance responses to $\mathrm{B}$ cell receptor (BCR) ligation such as calcium mobilization, IgM internalization, induction of activation markers or proliferation (14). Additionally, type I IFNs significantly augment the response of B cells to Toll-like receptor 7 (TLR7) ligands (16), and synergize with interleukin 6 (IL6) to promote the differentiation of B cells to antibody-secreting plasma cells (17). Thus, mammalian type I IFNs impact B cell functions through a wide range of direct effects or indirectly by regulating DCs or macrophages that in turn affect B cell functionality $(13,18,19)$. In this context, it is not surprising that the progression of systemic autoimmune diseases such as systemic lupus erythematosus (SLE) often associates with an increased type I IFN production (13), as IFN levels in SLE patients correlate with autoantibody production (20).

Teleost fish also possess multiple type I IFNs, varying in number depending on the fish species [reviewed in (21)]. The number of type I IFN genes is especially high in particular teleost lineages such as salmonids, potentially as a consequence of the additional whole genome duplication (WGD) event that took place throughout evolution in this lineage. Fish type I IFNs can be phylogenetically divided into three major groups (22), classified into 6 subgroups ( $\mathrm{a}, \mathrm{b}, \mathrm{c}, \mathrm{d}, \mathrm{e}$, and $\mathrm{f}$ ) in salmonids. IFNa, IFNd, and IFNe are in Group I, IFNb and IFNc are in Group II, whilst IFNf is in Group III, with multiple genes present for most subgroups (23). It is important to clarify that IFNa and IFNb are not orthologs of mammalian IFN $\alpha$ and IFN $\beta$. To date, the antiviral activity of several teleost type I IFNs has been confirmed, including IFNa, IFNb, and IFNc (2426). In contrast, IFNd showed little or no antiviral activity in salmon (or zebrafish) $(25,26)$. Whilst there is a single gene for IFN $\gamma$ in most vertebrate groups, again as a consequence of WGD, two genes are found in salmonids and cyprinids (27, 28). Although few functional studies have been undertaken in these species as to whether differences exist between the two IFN $\gamma$ paralogs, several independent transcriptional studies show no major differences concerning their regulatory mechanisms $(27,29-31)$. Interestingly, some teleost species [reviewed in (32)] have an additional IFN $\gamma$-like gene designated as IFN $\gamma$ rel that presumably originated from a teleost-specific tandem duplication. With regard to IFN $\gamma$ and IFN $\gamma$-rel bioactivity, most assays conducted thus far in teleosts have been predominantly focused on analyzing its effects on macrophages [reviewed in (32)].

In teleost fish, three Ig classes have been described to date, $\operatorname{IgM}, \operatorname{IgD}$, and IgT (a teleost-specific Ig) which define different B cell subsets. $\operatorname{IgM}^{+} \operatorname{IgD}^{+}$constitute the main B cell type in central immune tissues such as peripheral blood, spleen and head kidney (the main hematopoietic organ). As described in mammals, upon activation, these naïve cells loose surface $\operatorname{IgD}$ expression becoming $\operatorname{IgM}^{+} \operatorname{IgD}^{-}$cells (33). Additionally, as also reported in specific human and mice mucosal compartments (34-36), B cells exclusively expressing IgD on the cell surface have been identified in catfish (Ictalurus punctatus) blood (37) and rainbow trout (Oncorhynchus mykiss) gills (38) and intestine (39). The function of these cells is still unknown. $\operatorname{IgT}^{+}$cells, on the other hand, constitute a distinct $\mathrm{B}$ cell lineage that seems to be specialized in mucosal responses, as the ratio of $\operatorname{IgT}^{+} \mathrm{B}$ cells to $\operatorname{IgM}^{+} \operatorname{IgD}^{+} \mathrm{B}$ cells is higher in mucosal surfaces, and IgT responses have been shown to be restricted to mucosal compartments in response to some infections $(40,41)$. Interestingly, fish $\operatorname{IgM}^{+} \operatorname{IgD}^{+} \mathrm{B}$ cells have been shown to share many phenotypic and functional characteristics of mammalian B1 cells $(42,43)$, innate B cells that immediately respond to antigens to produce natural antibodies that interfere with pathogen replication until a specific immune response is mounted (44). In this context, it seemed quite relevant to establish how fish naïve $\operatorname{IgM}^{+} \operatorname{IgD}^{+} \mathrm{B}$ cells respond to innate signals produced during the early stages of a pathogenic exposure such as IFNs.

To date, whether type I or type II IFNs affect B cell functionality has been only addressed in fish in one study in which flounder (Paralichthys olivaceus) type I IFN was shown to enhance the phagocytic capacity of $\operatorname{IgM}^{+} \mathrm{B}$ cells as well as their production of reactive oxygen species (ROS) (45). In the current study, we have investigated the effects of both type I and type II IFN on $\operatorname{IgM}^{+}$B cells using rainbow trout (Oncorhynchus mykiss) as a model species. For this, we have stimulated rainbow trout peripheral blood leukocytes (PBLs) with recombinant trout IFNa and IFN $\gamma$ (rIFNa and rIFN $\gamma$ ) and then studied different functions of naïve B cells. We chose to undertake these studies with PBLs, as in rainbow trout, the blood is where the higher percentage of $\operatorname{IgM}^{+} \operatorname{IgD}^{+} \mathrm{B}$ cells are found, $\sim 44 \%$ (46). Our results demonstrate that while IFNa regulates many aspects of B cell functionality, type II IFN only has minor effects on IgM secretion. The effects of trout IFNa on naive B cells include increased survival through decreased apoptosis, up-regulated phagocytic capacity and augmented IgM secretion and $\mathrm{Mx}$ transcription. However, in contrast to mammalian type 
I IFN, trout IFNa was not capable of synergizing with BCR signaling. This study thus demonstrates that, in addition to their direct antiviral effects, teleost type I IFNs play an important role in the regulation of $\mathrm{B}$ cell responses as in mammals. The differences between the effects exerted in mammals and fish will most probably be a consequence of the significant differences that exist between mammalian conventional B cells and fish B cells.

\section{MATERIALS AND METHODS}

\section{Experimental Fish}

Healthy rainbow trout (Oncorhynchus mykiss) of $\sim 50-70 \mathrm{~g}$ were obtained from Piscifactoria Cifuentes (Cifuentes, Guadalajara, Spain) and maintained at the animal facilities of the Animal Health Research Center (CISA-INIA, Spain) in an aerated recirculating water system at $15^{\circ} \mathrm{C}$, with a $12: 12 \mathrm{~h}$ light: dark photoperiod. Fish were fed twice a day with a commercial diet (Skretting, Spain). Prior to any experimental procedure, fish were acclimatized to laboratory conditions for at least 2 weeks. During this period no clinical signs of disease were ever observed.

\section{Leukocyte Isolation}

Rainbow trout were killed with benzocaine (Sigma-Aldrich) and blood was extracted with a heparinized needle from the caudal vein. Blood was diluted 10 times with Leibovitz's medium (L15, Gibco) containing 100 I.U./ml penicillin and $100 \mu \mathrm{g} / \mathrm{ml}$ streptomycin (P/S, Life Technologies), 10 I.U./ml heparin and $5 \%$ fetal calf serum (FCS, Thermo Fisher Scientific) and then placed onto 51\% Percoll (GE Healthcare) density gradients. Cell suspensions were centrifuged at $400 \times g$ for $30 \mathrm{~min}$ at $4^{\circ} \mathrm{C}$, the interface cells were collected and washed with L-15 supplemented with antibiotics and 5\% FCS. The viable cell concentration was determined by Trypan blue (Sigma-Aldrich) exclusion and cells were resuspended in L-15 with 5\% FCS at a concentration of $2 \times$ $10^{6}$ cells $/ \mathrm{ml}$.

\section{Production of Recombinant IFNs}

rIFNa and rIFN $\gamma$ were produced as described previously (47, 48). Both recombinant proteins were expressed in Escherichia coli BL21 Star (DE3) by isopropyl $\beta$-D-1-thiogalactopyranoside (IPTG) induction and purified under denaturing conditions with extensive washing with buffer containing Triton X-100 to remove lipopolysaccharide (LPS) as described previously. The purified proteins were refolded in a buffer containing $0.5 \mathrm{M}$ arginine, and re-purified under native conditions (47-49). The bioactivity was established by testing their ability to induce the expression of specific target genes, such as Mx and CXCL11_L1 in vitro in rainbow trout cell lines such as the monocyte/macrophage rainbow trout cell line RTS11 $(47,48)$. Both proteins had no effects on the expression of known LPS-responsive genes, such as IL1 $\beta$ and cathelicidin-1 in RTS11 cells (50), confirming the lack of LPS contamination.

\section{Cell Stimulation}

Peripheral blood leukocytes (PBLs), suspended in L-15 medium supplemented with antibiotics and 5\% FCS, were dispensed into $24\left(2 \times 10^{6}\right.$ cells/well $)$ or 96 -well plates $\left(4 \times 10^{5}\right.$ cells/well) (Nunc), depending on the experiment. The rIFNa and $\mathrm{rIFN} \gamma$ were used at a final concentration of 50 and $20 \mathrm{ng} / \mathrm{ml}$, respectively, after establishing that these were the concentrations that rendered maximal effects in terms of B cell survival and $m x$ gene expression (data not shown). These concentrations are in accordance with previous results $(47,48,51)$. Controls incubated with media alone were included in all experiments. Leukocytes were cultured at $20^{\circ} \mathrm{C}$ for different times, depending on the experiment.

\section{Flow Cytometry}

Cells were stained with anti-trout IgM [1.14 mAb mouse IgG1 coupled to R-phycoerythrin (R-PE), $0.25 \mu \mathrm{g} / \mathrm{ml}$ ], anti-trout IgD [mAb mouse IgG1 coupled to allophycocyanin (APC), $4 \mu \mathrm{g} / \mathrm{ml}]$ and anti-trout MHC II $\beta$-chain [mAb mouse IgG1 coupled to fluorescein isothiocyanate (FITC), $4 \mu \mathrm{g} / \mathrm{ml}]$ for $1 \mathrm{~h}$ at $4^{\circ} \mathrm{C}$, as previously described (52-54). Antibodies were fluorescently labeled using R-PE, APC or FITC Lightning-Link labeling kits (Innova Biosciences) following the manufacturer's instructions. After the staining, cells were washed twice with staining buffer (phenol red-free L-15 medium supplemented with 2\% FCS). The cell viability was checked by addition of 4',6-diamine2'-phenylindole dihydrochlorid (DAPI, $0.2 \mu \mathrm{g} / \mathrm{ml}$ ). Cells were analyzed on a FACS Celesta flow cytometer (BD Biosciences) equipped with BD FACSDiva ${ }^{\mathrm{TM}}$ software. Flow cytometry analysis was performed with FlowJo V10 (TreeStar).

\section{Leukocyte Proliferation}

The Click-iT ${ }^{\mathrm{TM}}$ Plus EdU Alexa Fluor ${ }^{\mathrm{TM}} 488$ Flow Cytometry Assay Kit (Invitrogen ${ }^{\mathrm{TM}}$ ) was used to measure the proliferation of $\operatorname{IgM}^{+} \operatorname{IgD}^{+} \mathrm{B}$ cells following the manufacturer's instructions. PBLs were incubated for 3 days at $20^{\circ} \mathrm{C}$ in 96-well plates with the rIFNs or media alone. In some experiments, PBLs were also stimulated with unlabelled monoclonal antibody $(\mathrm{mAb})$ against trout IgM (clone 1.14, mouse IgG1) at a final concentration of $10 \mu \mathrm{g} / \mathrm{ml}$, to induce cross-linking of the BCR as described previously (43). After 3 days, $0.1 \mu \mathrm{M}$ of 5-ethynyl2'-deoxyuridine (EdU) was added to the cultures that were further incubated for $24 \mathrm{~h}$. Thereafter, cells were collected and stained with the LIVE/DEAD ${ }^{\circledR}$ Fixable Dead Cell Stain Kit (Invitrogen ${ }^{\mathrm{TM}}$ ) for $30 \mathrm{~min}$ at $4^{\circ} \mathrm{C}$ (protected from light) to check cell viability following the manufacturer's instructions. Subsequently the cells were stained with anti-trout IgM (1.14 $\mathrm{mAb}$ mouse IgG1 coupled to R-PE, $0.25 \mu \mathrm{g} / \mathrm{ml}$ ) and anti-trout IgD (mAb mouse IgG1 coupled to APC, $4 \mu \mathrm{g} / \mathrm{ml}$ ) for $1 \mathrm{~h}$ at $4^{\circ} \mathrm{C}$, as described above, and analyzed on a FACS Celesta flow cytometer.

\section{Apoptosis}

The apoptosis assay was performed using the PE Annexin V Apoptosis Detection Kit I (BD Pharmingen ${ }^{\mathrm{TM}}$ ) following the manufacturer's instructions. Briefly, PBLs were incubated for 48 or $72 \mathrm{~h}$ at $20^{\circ} \mathrm{C}$ in 96 -well plates with the rIFNs or with media alone. Thereafter, cells were stained with anti-trout IgM [1.14 $\mathrm{mAb}$ mouse IgG1 coupled to FITC, $0.425 \mu \mathrm{g} / \mathrm{ml}$ ] for $20 \mathrm{~min}$ at $4^{\circ} \mathrm{C}$. After washing with staining buffer, the cells were centrifuged at $400 \times g$ for $5 \mathrm{~min}$ at $4^{\circ} \mathrm{C}$, and $1.5 \mu \mathrm{l}$ of PE Annexin V 
and $4 \mu \mathrm{l}$ of 7 -aminoactinomycin D (7-AAD) per $200 \mu \mathrm{l}$ of $1 \mathrm{X}$ Annex V Binding Buffer added to the cells. The cells were then incubated for $15 \mathrm{~min}$ at room temperature (RT) in the dark before being transferred to flow cytometry tubes (Falcon ${ }^{\circledR} 5 \mathrm{~mL}$ Round Bottom Polystyrene Test Tube, Corning) containing $400 \mu \mathrm{l}$ of $1 \mathrm{X}$ Annex V Binding Buffer, and analyzed within $1 \mathrm{~h}$ on a FACS Celesta flow cytometer.

\section{Phagocytic Activity}

PBLs were seeded into 24-well plates and incubated for $72 \mathrm{~h}$ at $20^{\circ} \mathrm{C}$ with the rIFNs or media alone. The cells were then collected and resuspended in L-15 medium supplemented with antibiotics without serum and incubated for $3 \mathrm{~h}$ at $20^{\circ} \mathrm{C}$ with fluorescent beads (FluoSpheres ${ }^{\mathrm{TM}}$ Carboxylate-Modified Microspheres, $1.0 \mu \mathrm{m}$, crimson fluorescent (625/645), 2\% solids, Invitrogen ${ }^{\mathrm{TM}}$ ) at a cell: bead ratio of 1:10, as described before (55). After the incubation period, cells were harvested by gently pipetting, and non-ingested beads were removed by centrifugation $\left(100 \times g\right.$ for $10 \mathrm{~min}$ at $\left.4^{\circ} \mathrm{C}\right)$ over a cushion of $3 \%$ (weight/volume) bovine serum albumin (BSA) lyophilized powder, $\geq 96 \%$ (Sigma-Aldrich) in PBS supplemented with $4.5 \%$ (weight/volume) $\mathrm{D}(+)$-glucose monohydrate (Merck). Cells were then resuspended in staining buffer, labeled with antiIgM-FITC (1.14) $(0.425 \mu \mathrm{g} / \mathrm{ml})$ and anti-IgD-PE $(40 \mu \mathrm{g} / \mathrm{ml})$ and analyzed on a FACS Celesta flow cytometer. The cell viability was checked by staining the cells with DAPI $(0.2 \mu \mathrm{g} / \mathrm{ml})$. In some experiments, cytochalasin $\mathrm{B}(0.05 \mu \mathrm{g} / \mathrm{ml})$ was added to the cells immediately before the addition of the beads to verify active phagocytosis as described previously (55). Flow cytometry analysis was performed with FlowJo V10 to calculate the ratio between the percentage of phagocytic $\operatorname{IgM}^{+} \mathrm{B}$ cells among the total $\mathrm{IgM}^{+} \mathrm{B}$ cell population, the ratio between the percentage of highly phagocytic IgM ${ }^{+} \mathrm{B}$ cells among the total $\operatorname{IgM}^{+}$phagocytic $B$ cell population and the mean fluorescence intensity (MFI) of internalized beads in all $\operatorname{IgM}^{+}$phagocytic cells.

\section{ELISPOT Assay}

PBLs from individual fish were stimulated with rIFNs for $72 \mathrm{~h}$ at $20^{\circ} \mathrm{C}$ or left unstimulated in the same conditions in 96well plates. ELISPOT plates containing Inmobilon-P membranes (Millipore) were activated with $70 \%$ ethanol for $30 \mathrm{~s}$, coated with an anti-IgM mAb (clone $4 \mathrm{C} 10$ ) at $2 \mu \mathrm{g} / \mathrm{ml}$ in phosphate buffer saline (PBS) and incubated overnight at 4 ? $\mathrm{C}$. To block non-specific binding to the membrane, plates was incubated with $2 \%$ BSA in PBS for $2 \mathrm{~h}$ at RT. At this point, cells that had been stimulated with rIFNs for $72 \mathrm{~h}$ or unstimulated cells were transferred to the ELISPOT plates $\left(5 \times 10^{4}\right.$ cells/well $)$ and left overnight at $20^{\circ} \mathrm{C}$. The day after, cells were washed away five times with PBS and plates blocked again with $2 \%$ BSA in PBS for $1 \mathrm{~h}$ at RT. After blocking, biotinylated antiIgM mAb (clone 4C10) was added to the plates and incubated at $1 \mu \mathrm{g} / \mathrm{ml}$ for $1 \mathrm{~h}$ at RT. Following five washing steps (in PBS), the plates were developed using streptavidin-HRP (Thermo Scientific) for $1 \mathrm{~h}$ at RT, washed again with PBS and incubated with 3-amino-9-ethylcarbazole (Sigma-Aldrich) for $30 \mathrm{~min}$ at RT in the dark. Substrate reaction was stopped by washing the plates with tap water. Once the membranes had dried, they were digitally scanned and the number of spots in each welldetermined using an AID iSpot Reader System (Autoimmun Diagnostika GMBH).

\section{Cell Sorting}

PBLs were seeded into 24-well plates and incubated for $24 \mathrm{~h}$ with rIFNs or with media alone at $20^{\circ} \mathrm{C}$. At this point, cells were collected and incubated for $1 \mathrm{~h}$ at $4^{\circ} \mathrm{C}$ with anti-IgMFITC and anti-trout IgD-APC as described above. Following several washing steps, cells were resuspended in staining buffer and $\operatorname{IgM}^{+} \mathrm{IgD}^{+} \mathrm{B}$ cells isolated by flow cytometry using a BD FACSAria III cell sorter (BD Biosciences) based on their FSC/SSC profile and then on the basis of the fluorescence emitted by the anti-IgM and anti-IgD antibodies. Approximately $70,000 \mathrm{IgM}^{+} \mathrm{IgD}^{+} \mathrm{B}$ cells were collected in PBS for subsequent RNA isolation.

To confirm a direct effect of rIFNs on $\operatorname{IgM}^{+} \operatorname{IgD}^{+} \mathrm{B}$ cell survival, PBLs were incubated for $1 \mathrm{~h}$ at $4^{\circ} \mathrm{C}$ with a biotinyilated Fab fragment of anti-IgM 1.14 (to avoid cell activation) in staining buffer. Following two washing steps, Streptavidin-Phycoerythrin (PE) (BD Pharmingen) was added. After $20 \mathrm{~min}$ at $4^{\circ} \mathrm{C}$, cells were resuspended in staining buffer and $\operatorname{IgM}^{+} \operatorname{IgD}^{+} \mathrm{B}$ cells isolated as described above. Sorted $\operatorname{IgM}^{+} \operatorname{IgD}^{+} \mathrm{B}$ cells were then incubated with rIFNs or media alone for 3 days at $20^{\circ} \mathrm{C}$. After this time, cells were counterstained with $0.2 \mu \mathrm{g} / \mathrm{ml}$ DAPI, and analyzed on a FACS Celesta flow cytometer.

\section{Real Time PCR Analysis}

Total RNA was isolated from FACS sorted $\operatorname{IgM}^{+} \operatorname{IgD}^{+}$B cells using the Power SYBR Green Cells-to-Ct Kit (Invitrogen), following the manufacturer's instructions. Briefly, total RNA was treated with DNase during the process to remove genomic DNA that might interfere with the PCR reactions and then reverse transcribed into cDNA following the manufacturer's instructions. To evaluate the levels of transcription of the different genes, real time RT-PCR was performed with a LightCycler ${ }^{\circledR} 96$ System instrument (Roche) using SYBR Green PCR core Reagents (Applied Biosystems) and specific primers (Table S1). Samples obtained from individual fish were analyzed in duplicate under the following conditions: $1 \mathrm{~min}$ at $95^{\circ} \mathrm{C}$, followed by 45 amplification cycles $\left(15 \mathrm{~s}\right.$ at $95^{\circ} \mathrm{C}$ and $1 \mathrm{~min}$ at $60^{\circ} \mathrm{C}$ ). A melting curve for each primer set was obtained by reading fluorescence every degree between 60 and $95^{\circ} \mathrm{C}$ to ensure that only a single PCR product had been amplified. The expression of individual genes was normalized to the relative expression of the housekeeping gene $\beta$-actin, and the expression levels were calculated using the $\left.2^{(}-\Delta \mathrm{Ct}\right)$ method, where $\Delta \mathrm{Ct}$ is determined by subtracting the $\beta$ actin value from the target $\mathrm{Ct}$ (Ct cut-off set to 38). This housekeeping gene was selected after verifying that no statistical differences were detected among $\beta$-actin $\mathrm{Ct}$ values obtained from different samples. Negative controls with no template and minus reverse transcriptase controls were included in all the assays. 
A

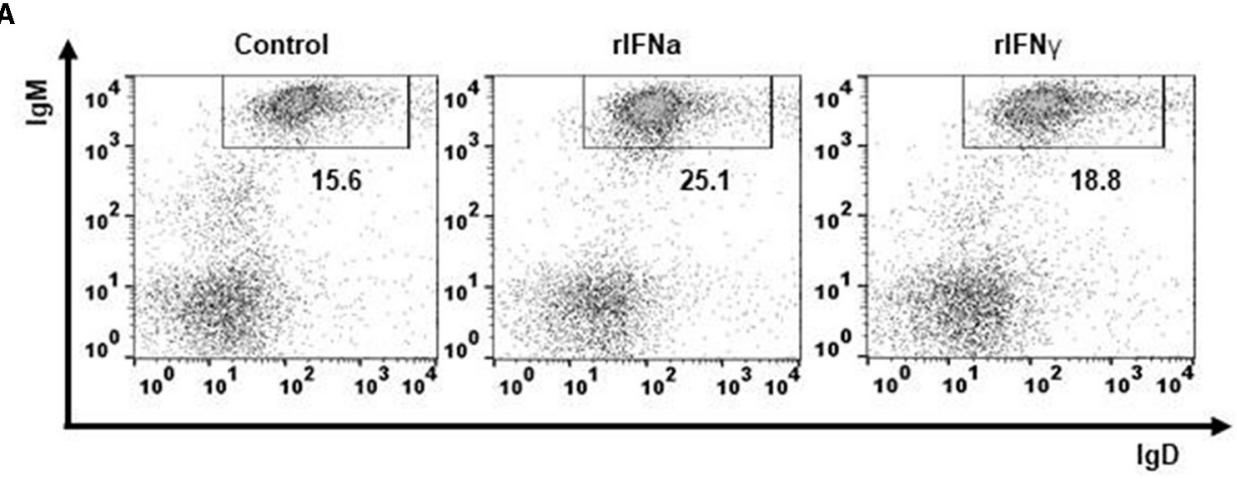

B
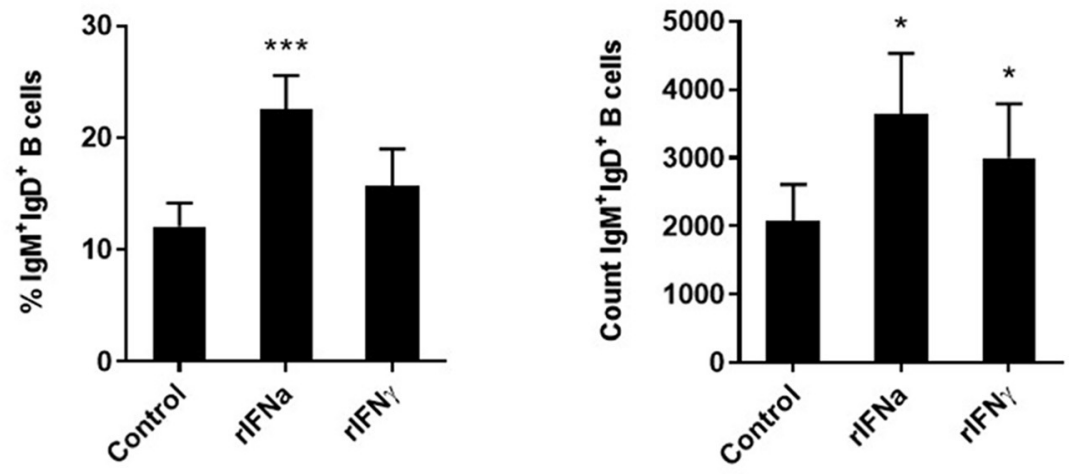

C
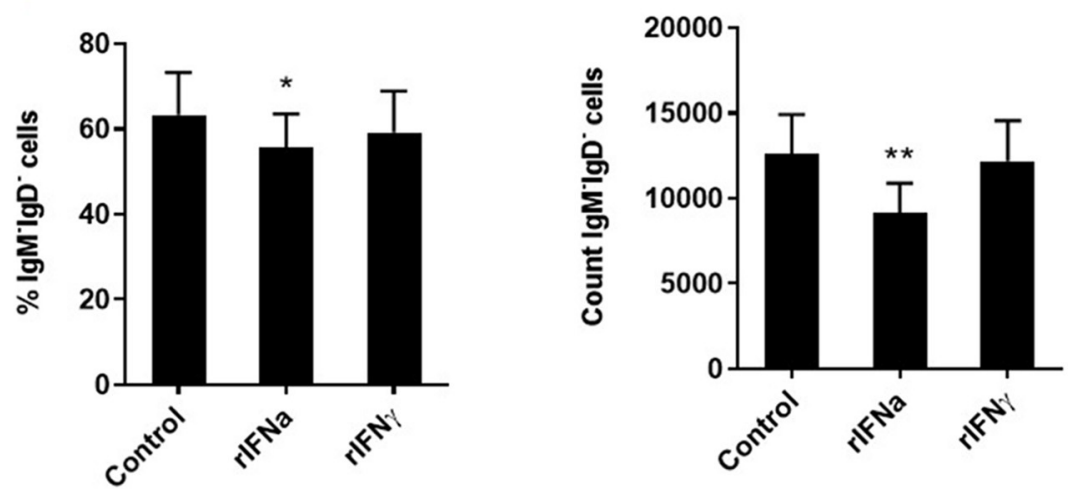

D
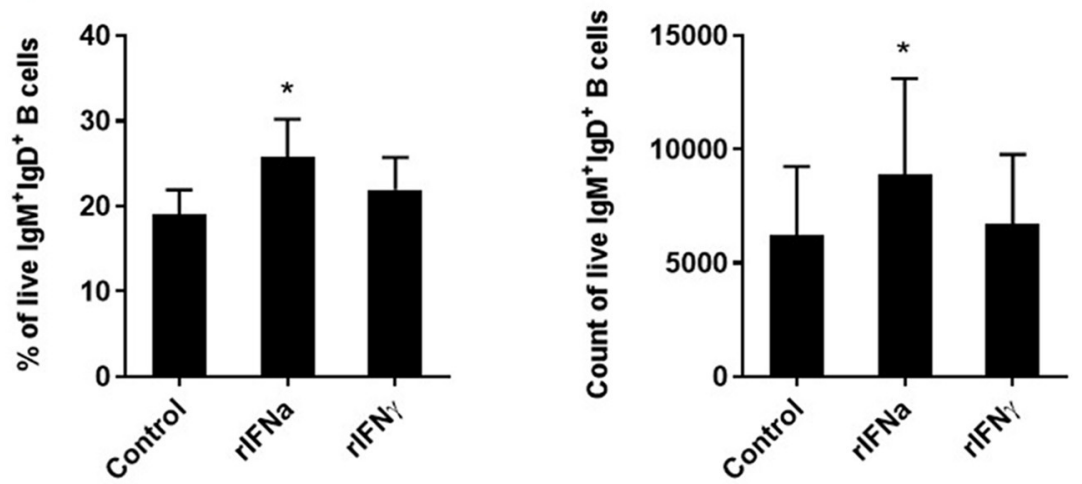

FIGURE 1 | Survival of blood lgM+ $\mathrm{IgD}^{+}$B cells in response to type I and type II IFNs. PBLs were stimulated with $50 \mathrm{ng} / \mathrm{ml} \mathrm{rlFNa}, 20 \mathrm{ng} / \mathrm{ml} \mathrm{rlFN} \gamma$ or media alone (control) and cultured at $20^{\circ} \mathrm{C}$ for $72 \mathrm{~h}$. Leukocytes were then labeled with specific monoclonal antibodies against trout lgM and lgD and analyzed by flow cytometry. 
FIGURE 1 | Cells were gated on the basis of their FSC and SSC and percentages of $\operatorname{lgM}^{+} \lg D^{+}$cells determined on singlet and live (DAPI negative) cells. Representative dot plots from one individual fish are shown (A) along with mean percentages and total number of cells detected for $\lg \mathrm{M}^{+} \lg \mathrm{D}^{+} \mathrm{B}$ cells $(\mathbf{B})$ and $\operatorname{lgM}^{-} \lg D^{-}$cells (C) (mean + SEM; $n=9$ ). In an independent experiment, B cells were sorted from blood leukocytes using a biotinyilated Fab fragment of anti-lgM 1.14 and then incubated with the rIFNs as described above. After $72 \mathrm{~h}$, the percentage of live $\operatorname{lgM}{ }^{+} \lg D^{+} B$ cells and the total number of live $\operatorname{lgM}{ }^{+} \lg D^{+} B$ cells determined by flow cytometry as described in the Materials and Methods section (mean $+\mathrm{SEM} ; n=7$ ) (D). Asterisks denote significant differences between samples treated with rIFNs and control samples $\left({ }^{*} P \leq 0.05,{ }^{* \star} P \leq 0.01,{ }^{\star \star *} P \leq 0.001\right)$.

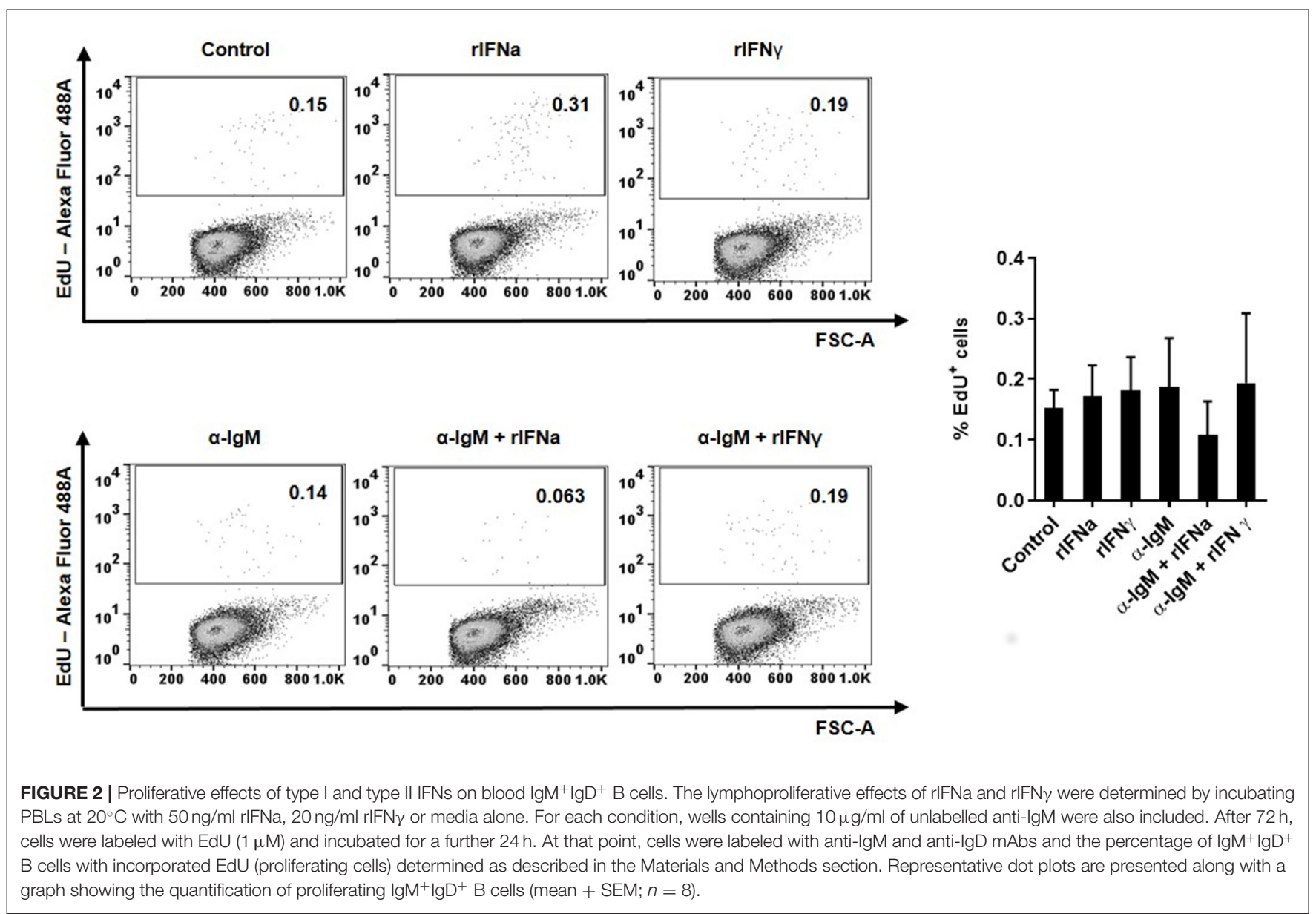

\section{Statistical Analysis}

Data handling, analysis and graphic representation were performed using GraphPad Prism version 7.00 for Windows, GraphPad Software, La Jolla California USA (www.graphpad. com). Statistical analyses were performed using a two-tailed Student's $t$-test and the differences between the mean values were considered significant when $P \leq 0.05$.

\section{RESULTS}

\section{Type I IFNa Increases the Survival of $\lg \mathrm{M}^{+} \lg \mathrm{D}^{+} \mathrm{B}$ Cells by Decreasing Their Spontaneous Apoptosis}

Our results show that the incubation of rainbow trout PBLs with rIFNa significantly increased the survival of $\operatorname{IgM}^{+} \operatorname{IgD}^{+} \mathrm{B}$ cells after $72 \mathrm{~h}$ (Figures 1A,B). In this and all other flow cytometry experiments described throughout the paper with the exception of the apoptosis assays, doublets and dead cells were excluded from the analysis following the gating strategy described in Figure S1. rIFNa significantly increased both the percentage of $\operatorname{IgM}^{+} \mathrm{B}$ cells and the absolute number of $\operatorname{IgM}^{+} \mathrm{B}$ cells in the cultures (Figures 1A,B), while rIFN $\gamma$ only had a significant effect increasing the absolute number of $\operatorname{IgM}^{+} \mathrm{B}$ cells in the cultures but had no effect on the percentage of $\operatorname{IgM}^{+}$B cells (Figures 1A,B). $\operatorname{rIFN} \gamma$ had no effect on the survival of the $\operatorname{IgM}^{-}$leukocyte population, whereas rIFNa provoked a slight but significant down-regulation of the percentage and the total number of $\mathrm{IgM}^{-}$ cells in the cultures (Figures 1A,C). In these experiments, rIFNa and $\mathrm{rIFN} \gamma$ were used at their optimal concentrations $(50 \mathrm{ng} / \mathrm{ml}$ and $20 \mathrm{ng} / \mathrm{ml}$, respectively), as established before $(47,48,51)$, and in preliminary experiments, where in the case of rIFN $\gamma$ higher concentrations $(50 \mathrm{ng} / \mathrm{ml})$ had similar or even lower effects on $\operatorname{IgM}^{+} \mathrm{IgD}^{+}$B cells (Figure S2). As this effect of rIFNa 
A
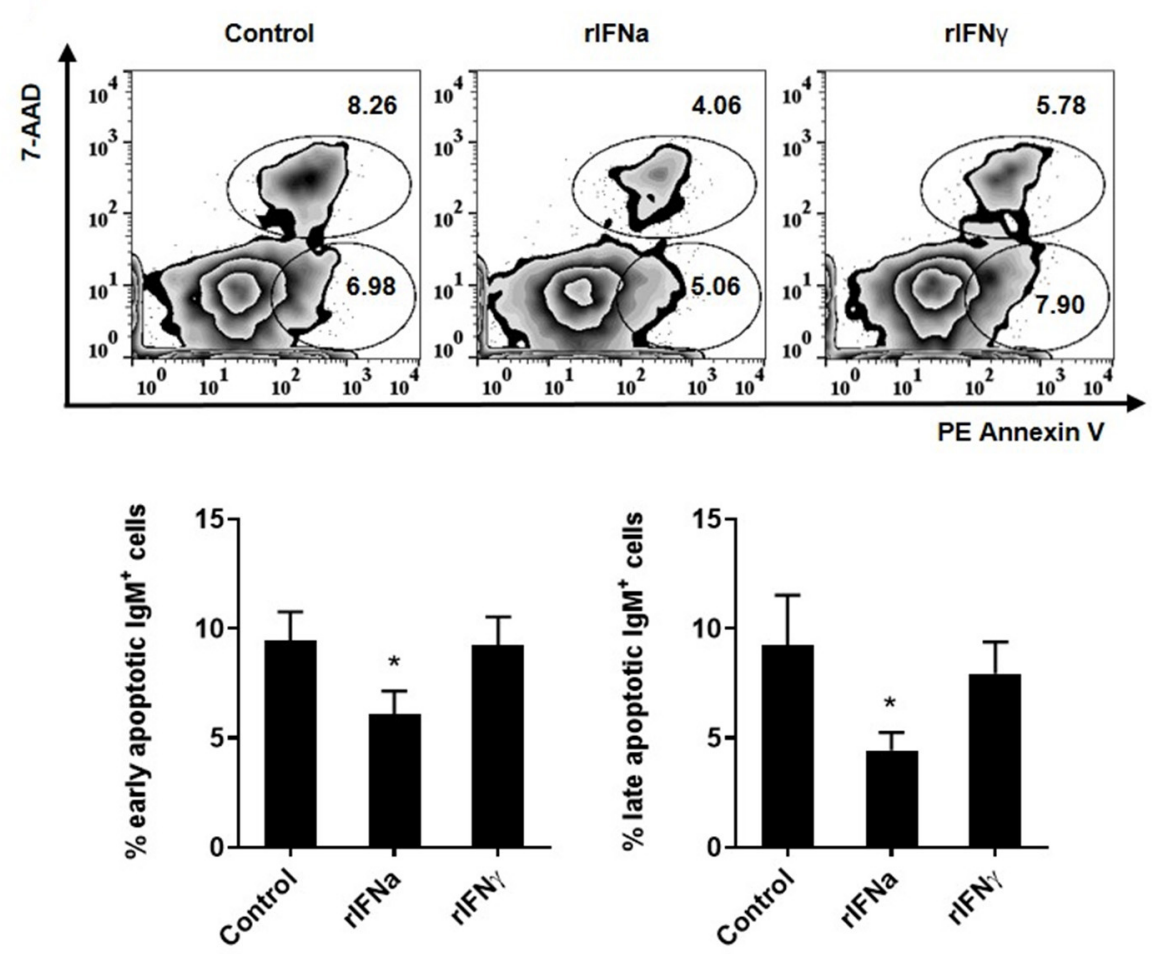

B
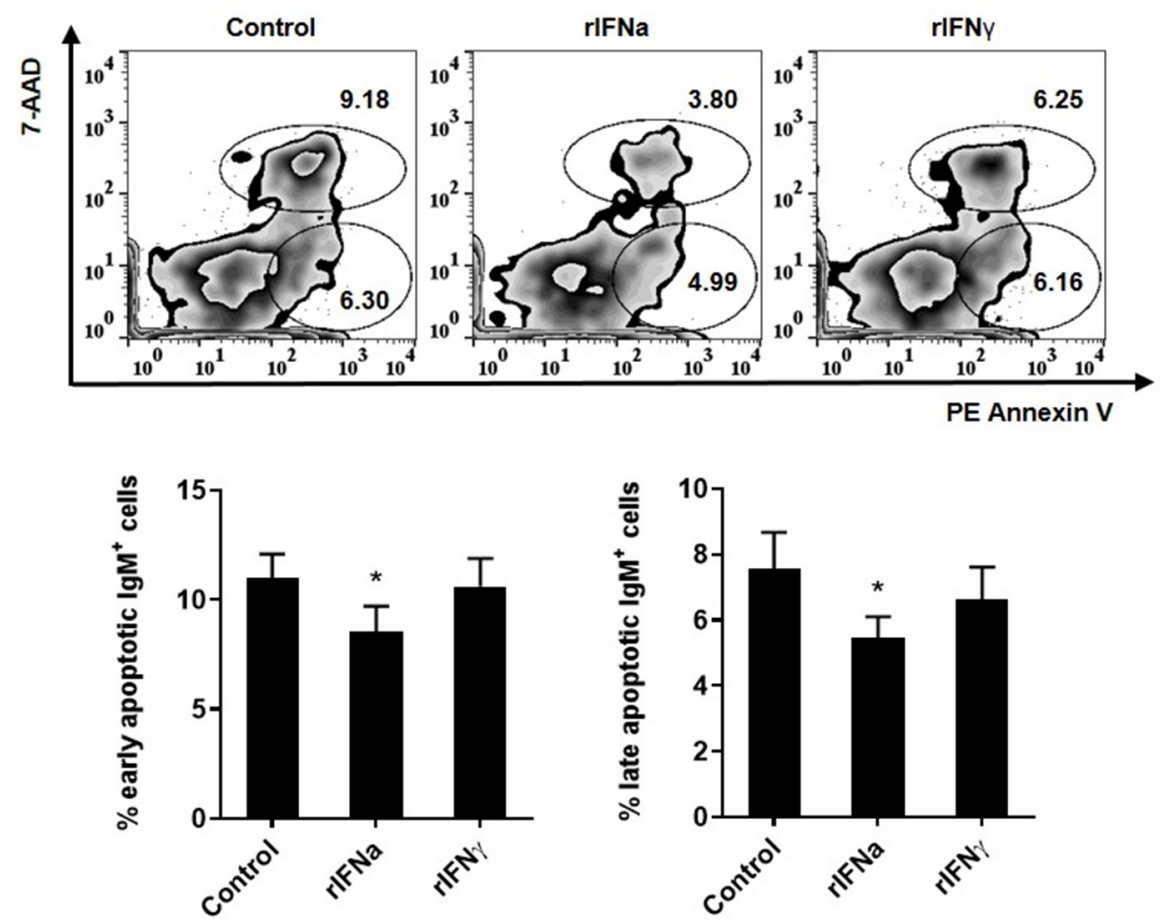

FIGURE 3 | Effect of type I and type II IFNs on the spontaneous apoptosis of blood lgM ${ }^{+} \lg D^{+}$B cells. PBLs were incubated for $48 \mathrm{~h}$ (A) or $72 \mathrm{~h}$ (B) at $20^{\circ} \mathrm{C}$ with $50 \mathrm{ng} / \mathrm{ml} \mathrm{rlFNa}, 20 \mathrm{ng} / \mathrm{ml} \mathrm{rlFN} \gamma$ or media alone (control). Then, cells were stained with anti-trout lgM for $20 \mathrm{~min}$ at $4^{\circ} \mathrm{C}$. After washing, PE Annexin $\mathrm{V}$ and $7-\mathrm{AAD}$ were 
FIGURE 3 | used to stain the cells and identify early (Annexin $\mathrm{V}^{+} / 7-\mathrm{AAD}^{-}$) and late (Annexin $\mathrm{V}^{+} / 7-\mathrm{AAD}^{+}$) apoptosis. Data were analyzed within $1 \mathrm{~h}$ as described in the Materials and Methods section. Representative dot plots are presented along with graphs showing the quantification of apoptotic lgM ${ }^{+} \mathrm{B}$ cells $($ mean $+\mathrm{SEM} ; n=$ 6-9). Asterisks denote significant differences between samples treated with rIFNs and control samples ( $\left.{ }^{*} P \leq 0.05\right)$.

on $\operatorname{IgM}^{+} \operatorname{IgD}^{+} \mathrm{B}$ cells could have been indirect, we repeated the experiments in such a way that $\operatorname{IgM}^{+} \operatorname{IgD}^{+} \mathrm{B}$ cells were first sorted with an anti-IgM Fab and then stimulated with the rIFNs. The purity of the sorted B cell population was evaluated by flow cytometry (Figure S3). In this case again, only rIFNa significantly increased the survival of $\operatorname{IgM}^{+} \operatorname{IgD}^{+} \mathrm{B}$ cells, demonstrating a direct effect of this cytokine on survival (Figure 1D).

To determine whether this increased survival of B cells in the presence of rIFNa was a consequence of lymphoproliferative effects of this cytokine, we analyzed the proliferative effect of rIFNa and rIFN $\gamma$ on their own or when combined with BCR cross-linking (through incubation with anti-IgM). Our results clearly showed that none of the rIFNs exerted significant proliferative effects on rainbow trout blood $\operatorname{IgM}^{+} \operatorname{IgD}^{+} \mathrm{B}$ cells by themselves (Figure 2). No synergistic effects were observed between BCR cross-linking and rIFN stimulation (Figure 2).

Another possible mechanism through which rIFNa could increase the survival of $\operatorname{IgM}^{+} \operatorname{IgD}^{+} \mathrm{B}$ cells may be through the modulation of spontaneous apoptosis of these cells. To test this, we studied apoptosis of $\operatorname{IgM}^{+} \operatorname{IgD}^{+} \mathrm{B}$ cells after 48 or $72 \mathrm{~h}$ of incubation with the different rIFNs. In these experiments, the leukocyte population was gated and doublets excluded from the analysis as described in Figure S1, although in this case the viability marker used was 7-AAD. Both after 48 and $72 \mathrm{~h}$, a significant decrease in the percentage of early $\left(\right.$ Annexin $\left.\mathrm{V}^{+} / 7-\mathrm{AAD}^{-}\right)$and late $\left(\right.$Annexin $\mathrm{V}^{+} / 7-\mathrm{AAD}^{+}$) apoptotic $\operatorname{IgM}^{+} \operatorname{IgD}^{+} \mathrm{B}$ cells was observed after stimulation with rIFNa (Figures 3A,B). Interestingly, the percentages of early and late apoptotic $\operatorname{IgM}^{+} \operatorname{IgD}^{+} \mathrm{B}$ cells were quite similar after 48 and $72 \mathrm{~h}$ suggesting that $\mathrm{B}$ cells are mostly killed during the first $48 \mathrm{~h}$ of culture, whereas those that survive after $48 \mathrm{~h}$ remain viable for longer time periods. This effect was not observed in response to $\mathrm{rIFN} \gamma$. Altogether, our results demonstrate that rIFNa increases the survival of blood naïve B cells, rescuing them from spontaneous apoptosis.

\section{Type I IFNa Increases the Phagocytic Activity of $\lg \mathrm{M}^{+} \lg \mathrm{D}^{+} \mathrm{B}$ Cells}

As teleost B cells have been shown to have a potent phagocytic activity (42), we also investigated if rIFNa and $\operatorname{rIFN} \gamma$ had an effect on the capacity of $\operatorname{IgM}^{+} \operatorname{IgD}^{+} \mathrm{B}$ cells to phagocytise microparticles. For this, PBLs were pre-treated with the rIFNs and after $72 \mathrm{~h}$, the phagocytosis assay was conducted. Our results show that the pre-stimulation of $\operatorname{IgM}^{+} \mathrm{IgD}^{+} \mathrm{B}$ cells with $\mathrm{rIFNa}$ significantly increased the percentage of phagocytic $\operatorname{IgM}^{+} \operatorname{IgD}^{+} \mathrm{B}$ cells in the cultures when compared to either unstimulated cells or those treated with rIFN $\gamma$ (Figure 4). Additionally, the MFI of internalized beads in blood $\operatorname{IgM}^{+} \mathrm{IgD}^{+} \mathrm{B}$ cells was significantly higher in rIFNa-treated cells compared to controls (Figure 4), as was percentage of $\operatorname{IgM}^{+} \mathrm{IgD}^{+} \mathrm{B}$ cells with a high number of ingested beads (highly phagocytic $\operatorname{IgM}^{+} \operatorname{IgD}^{+} \mathrm{B}$ cells) (Figure 4).
When we analyzed the effect of these cytokines on the $\operatorname{IgM}^{-} \operatorname{IgD}^{-}$ population, we found that in this case IFNa had positive effects on the percentage of phagocytic cells, whereas both cytokines increased the percentage of highly phagocytic cells in the cultures when compared to unstimulated cells.

\section{Type I and Type II IFN Increase IgM Secretion}

We next studied, through ELISPOT, whether the rIFNs affected the capacity of rainbow trout blood B cells to secrete IgM, by determining the number of IgM-secreting cells (plasmablasts or plasma cells) in these PBL cultures. In this case, both rIFNa and rIFN $\gamma$ significantly increased the number of IgM-secreting cells in the cultures after 3 days when compared to the number of IgM-secreting cells found in non-stimulated cultures (Figure 5), although the response to rIFNa was significantly higher than that of $\mathrm{rIFN} \gamma$.

\section{rIFNs Have No Effect on the Antigen Presenting Capacities of Blood $\lg \mathrm{M}^{+} \lg \mathrm{D}^{+}$ B Cells}

In mammals, IFN $\gamma$ is one of the main cytokines involved in stimulating MHC class II expression in antigen presenting cells (56). Likewise, stimulation of rainbow trout RTS11 macrophages with $10 \mathrm{ng} / \mathrm{ml}$ of $\mathrm{rIFN} \gamma$ significantly increased MHC class II transcription between 24 and $72 \mathrm{~h}$ post-stimulation (51). In this context, we examined whether rIFN $\gamma$ and rIFNa could modulate MHC II expression in blood $\operatorname{IgM}^{+} \operatorname{IgD}^{+} \mathrm{B}$ cells, as they are also antigen presenting cells. We first evaluated MHC-II surface expression by flow cytometry using a specific anti-trout MHCII. No significant modulation of MHC II surface expression (Figure 6A) or MHC II transcription (Figure 6C) was observed in $\mathrm{IgM}^{+} \mathrm{IgD}^{+} \mathrm{B}$ cells. Additionally, we evaluated the effect of rIFNs on the level of transcription of CD80/86 and CD83, co-stimulatory molecules involved in antigen presentation, and again no effect was found (Figure 6C). Interestingly, both rIFNa and $\mathrm{rIFN} \gamma$ significantly increased the levels of surface MHC II in $\mathrm{IgM}^{-}$cells in these cultures (Figure 6B). These results suggest that rIFNa and rIFN $\gamma$ do not modulate the antigen presenting capacities of rainbow trout B cells, despite having effects on other antigen presenting cells, possibly monocytes/macrophages.

\section{Type I IFNs Induce the Transcription of Several Mx Proteins in Blood $\lg \mathrm{M}^{+} \lg \mathrm{D}^{+} \mathrm{B}$ Cells}

Mx proteins are dynamin-like GTPases, which play an important role in antiviral immunity (57) Mammalian Mx expression is generally induced by type I and type III IFNs but not by type II IFN (58), although some exceptions to this general rule have been found recently in teleost fish (59). Interestingly, it has also been shown recently that the Mx family of proteins has expanded in 


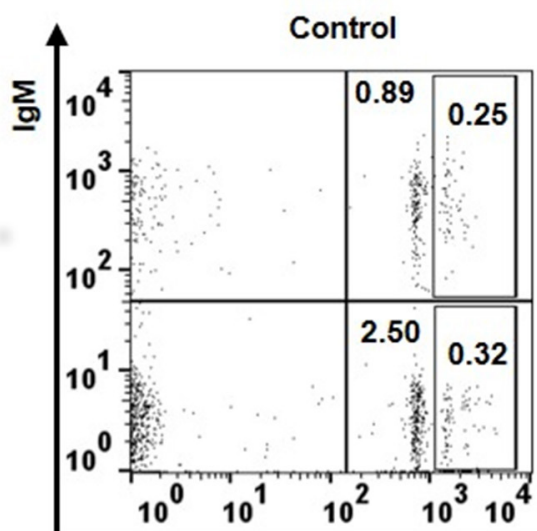

rIFNa

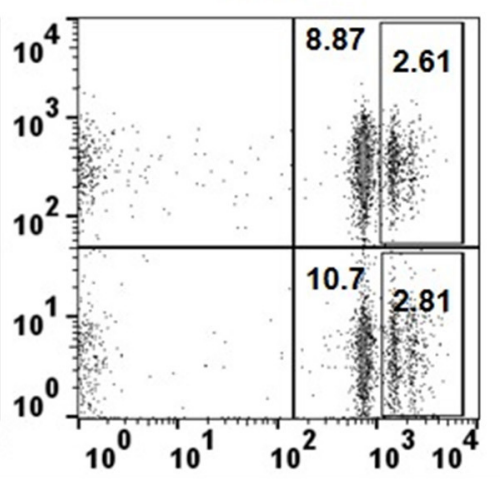

rIFNy

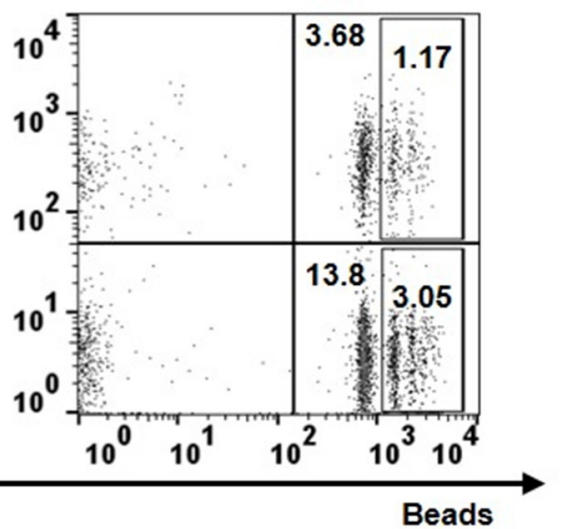

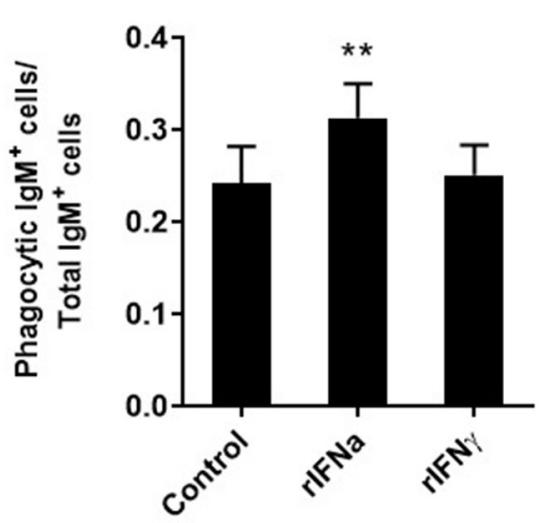
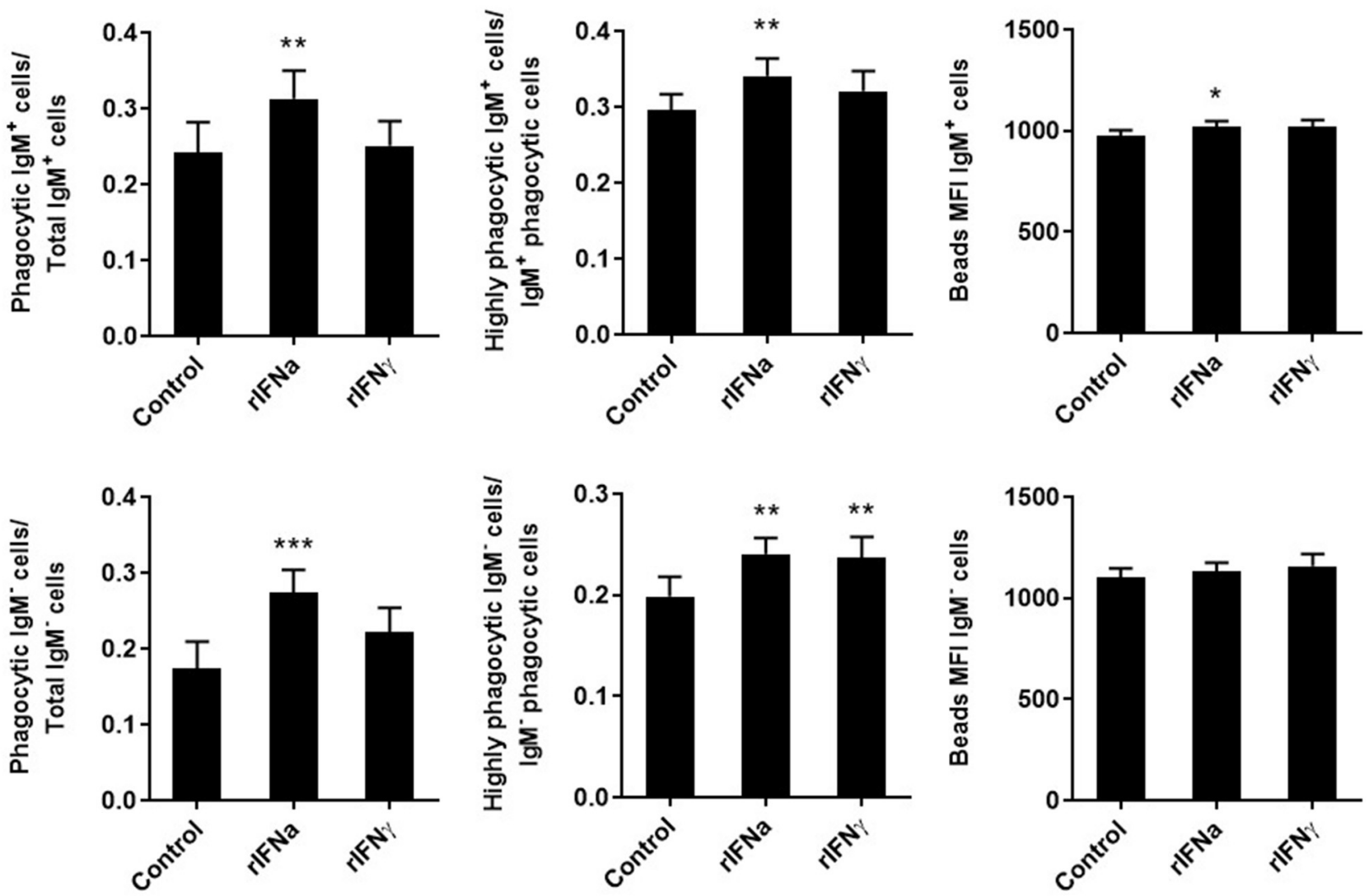

FIGURE 4 | Effect of type I and type II IFNs on the phagocytic capacity of blood lgM ${ }^{+} \operatorname{lgD}^{+} \mathrm{B}$ cells. PBLs were incubated for $72 \mathrm{~h}$ at $20^{\circ} \mathrm{C}$ with $50 \mathrm{ng} / \mathrm{ml}$ rlFNa, $20 \mathrm{ng} / \mathrm{ml} \mathrm{rIFN} \gamma$ or media alone (control). After this time, cells were incubated with crimson red fluorescent beads (1 $\mu \mathrm{m}$ diameter) at a ratio of $1: 10$ (cells/ beads) for a further $3 \mathrm{~h}$ at $20^{\circ} \mathrm{C}$ and the phagocytic capacity of B cells established as described in materials and methods. Representative dot plots for each experimental condition are shown. The rectangular areas contain the highly phagocytic cell subpopulations (cells that have internalized a higher number of beads) among lgM ${ }^{+}$ (upper) or IgM $^{-}$(lower) cell sub-populations. Upper graphs show the percentage of phagocytic lgM ${ }^{+} \mathrm{B}$ cells within the total IgM+ $\mathrm{B}^{+}$cell population (left), the percentage of highly $\operatorname{lgM}^{+}$phagocytic cells within the total phagocytic $\operatorname{lgM}^{+} \mathrm{B}$ cell population (middle) and the mean fluorescence intensity (MFI) of internalized beads within phagocytic IgM+ $\mathrm{IM}^{+}$cells (right). Lower graphs show the same information for the IgM $^{-}$population. Data are means $+\mathrm{SEM} ; n=10$. Asterisks denote significant differences between samples treated with rIFNs and control samples $\left({ }^{\star} P \leq 0.05,{ }^{\star \star} P \leq 0.01,{ }^{\star \star \star} P \leq 0.001\right)$. 


\section{Control}

3

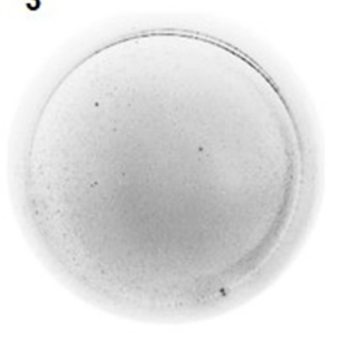

rIFNa

16

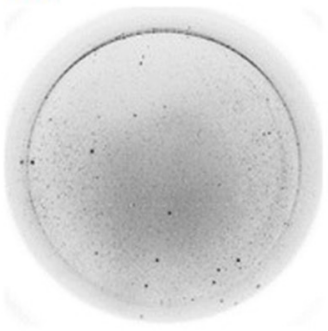

rIFNY

7

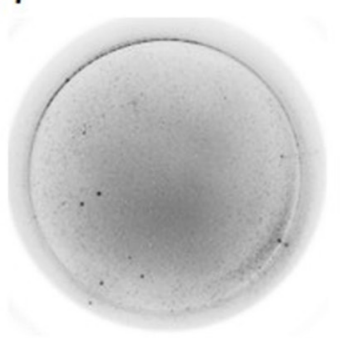

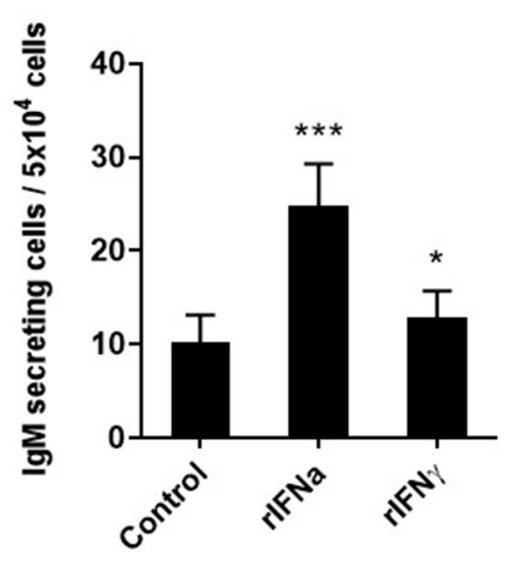

FIGURE 5 | Effect of type I and type II IFNs on the differentiation of IgM+ $\mathrm{IgD}^{+}$B cells to IgM-secreting cells. PBLs were treated with $50 \mathrm{ng} / \mathrm{ml} \mathrm{rlFNa}, 20 \mathrm{ng} / \mathrm{ml} \mathrm{rlFN} \gamma$ or media alone (control) and incubated for $72 \mathrm{~h}$ at $20^{\circ} \mathrm{C}$. Thereafter, cells were added to ELISPOT plates, previously coated with anti-lgM mAb $(2 \mu \mathrm{g} / \mathrm{ml})$, and incubated for a further $24 \mathrm{~h}$. The number of IgM-secreting cells was then detected as described in Materials and Methods. Representative wells from one individual are shown along with the quantification of spot-forming cells (mean $+\mathrm{SEM} ; n=12$ ). Asterisks denote significant differences between samples treated with rIFNs and control samples $\left({ }^{\star} P \leq 0.05,{ }^{* \star *} P \leq 0.001\right)$.

salmonids, with 10 different $m x$ genes present in Atlantic salmon and 9 in rainbow trout (48). However, to date, $\mathrm{Mx}$ expression has not been studied to our knowledge in fish B cells. Our results demonstrate that rIFNa significantly induced the transcription of Mx1, Mx3, and Mx5 (Figure 7) in sorted blood $\operatorname{IgM}^{+} \operatorname{IgD}^{+}$ $B$ cells and significantly up-regulated the mRNA levels of $\mathrm{Mx} 2$, constitutively transcribed by these cells (Figure 7). rIFN $\gamma$, on the other hand, had no significant effects on $\mathrm{Mx}$ transcription (Figure 7).

\section{DISCUSSION}

In addition to the well-known direct antiviral effects of type I IFNs and the ability of type II IFN to modulate antigen presentation, it has now become evident that IFNs are also involved in the regulation of lymphocyte development and differentiation. However, it is generally believed that B cells are mainly modulated by type I IFN, while T cells are mostly responsive to type II IFN (60). To investigate whether fish B cells are also responsive to type I IFNs, we have studied the effects of a model type I trout IFN protein (IFNa) on naïve blood B cells and compared the effects to those elicited by type
II IFN produced under the same conditions. In these assays, the optimal concentrations for each rIFN were previously established and were different for each protein $(50 \mathrm{ng} / \mathrm{ml}$ for IFNa and $20 \mathrm{ng} / \mathrm{ml}$ for IFN $\gamma$ ), in concordance with previous publications $(47,48,51)$. Having said this, all the assays described in the current study were initially performed with IFN $\gamma$ at $50 \mathrm{ng} / \mathrm{ml}$ but no significant differences with the results presented here were found (Figure S2).

The first effect that was clearly visible when PBLs were incubated with IFNa was that both the percentage of $\operatorname{IgM}^{+} \mathrm{IgD}^{+}$ $\mathrm{B}$ cells and the absolute number of $\operatorname{IgM}^{+} \mathrm{IgD}^{+} \mathrm{B}$ cells increased significantly in the cultures in the presence of the cytokine after $72 \mathrm{~h}$. As many other leukocyte types were also present in these cultures, it could have been possible that this increase in B cells was a consequence of IFNa affecting other cell types that afterwards activated B cells. For example, mammalian type I IFN, produced during the course of a viral infection, can activate DCs and macrophages to produce BAFF and APRIL which in turn activate B cells (19). Hence, to rule out possible indirect effects in our experiments, we sorted trout blood B cells and then stimulated them with rIFNa. In this case, similar positive effects on $\mathrm{B}$ cell survival were observed, pointing to 
A

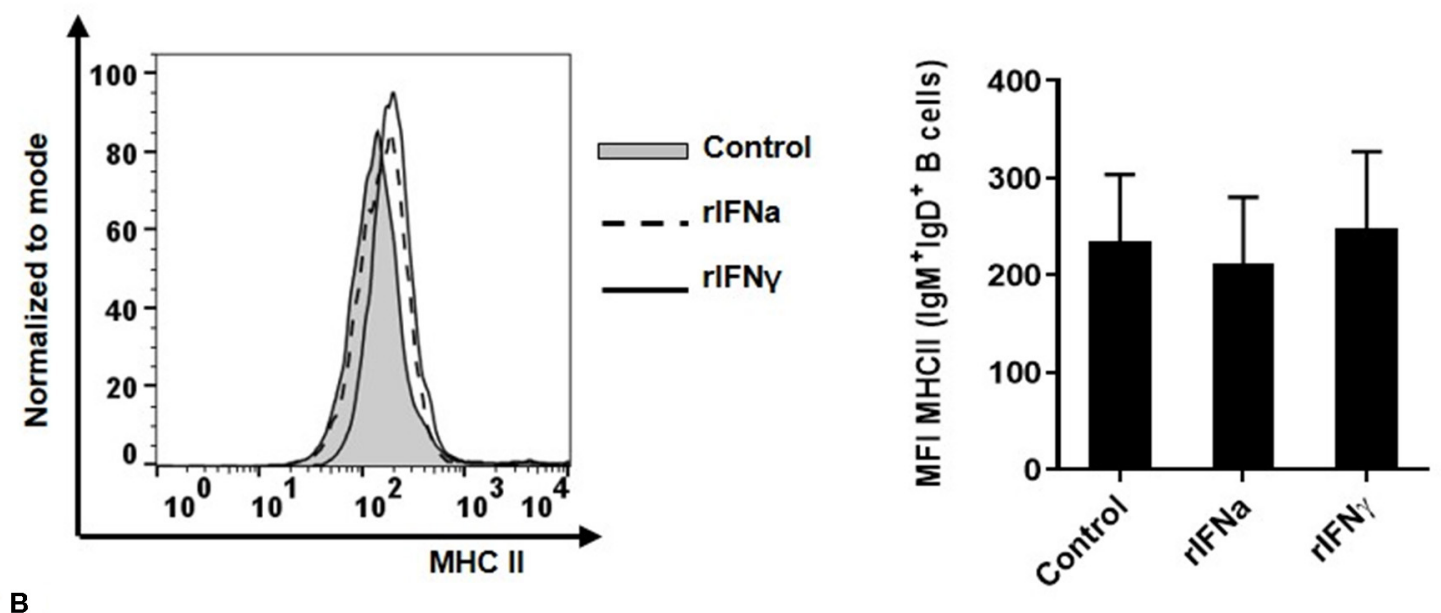

B
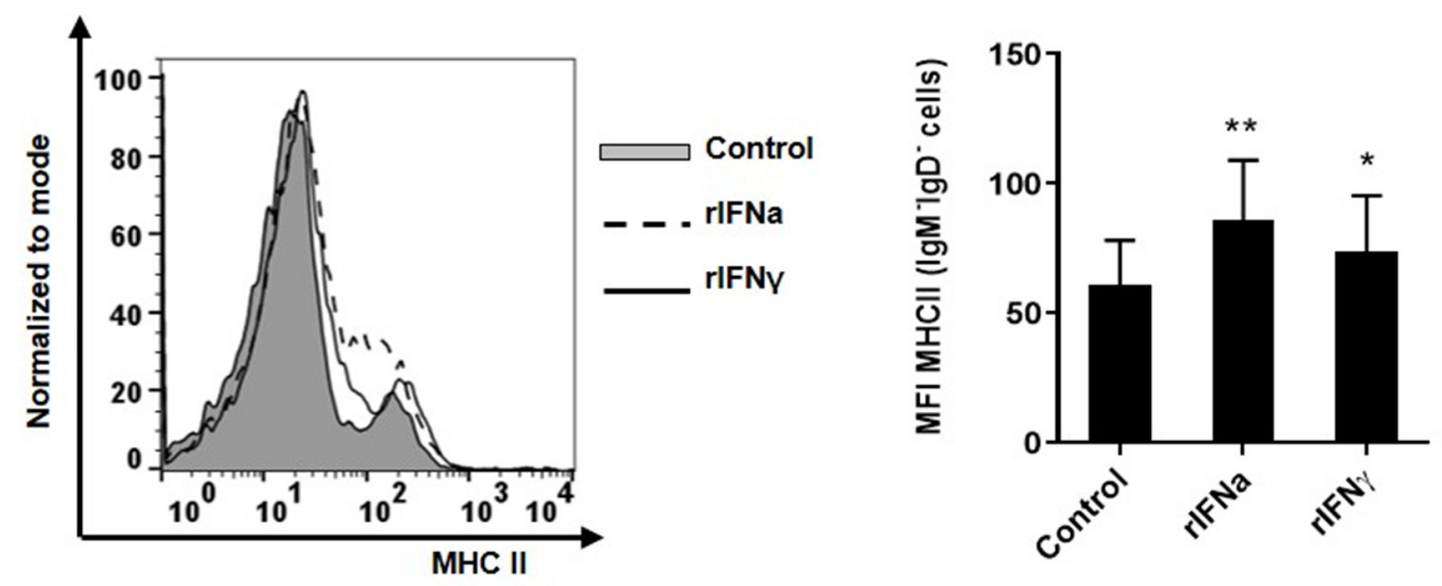

C
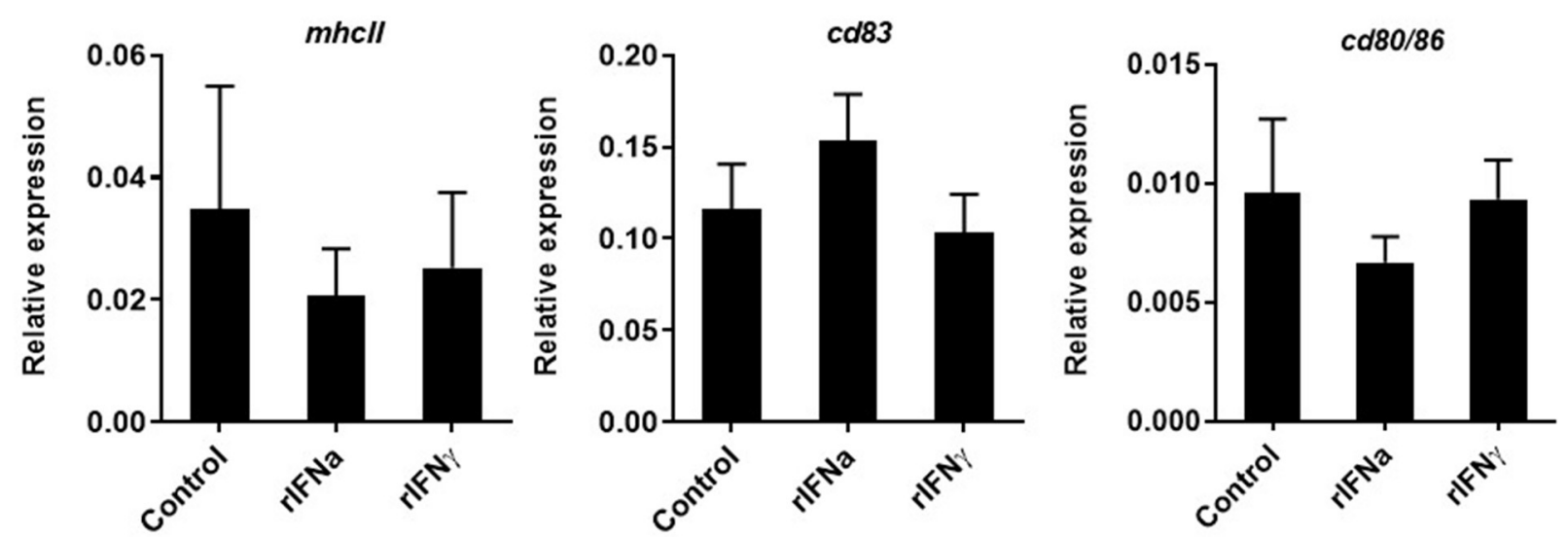

FIGURE 6 | Effect of type I and type II IFNs on the antigen-presenting capacities of blood cells. PBLs were incubated with $50 \mathrm{ng} / \mathrm{ml} \mathrm{rlFNa}, 20 \mathrm{ng} / \mathrm{ml} \mathrm{rIFN} \gamma$ or media

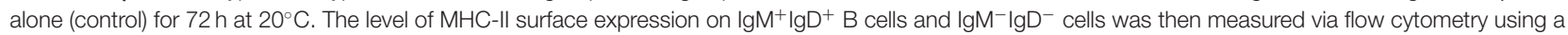


FIGURE 6 | specific mAb against trout MHC-II. A representative histogram is shown together with a graph of the mean $\mathrm{MHC}^{-1 I} \mathrm{MFI}$ values for $\operatorname{lgM}{ }^{+} \lg \mathrm{D}^{+} \mathrm{B}$ cells $(\mathbf{A})$ or $\operatorname{lgM}^{-} \lg D^{-}$cells (B) (mean $+\mathrm{SEM} ; n=9$ ). In another experiment, blood leukocytes were treated with the rlFNs as described above and after $24 \mathrm{~h} \mathrm{IgM}^{+} \lg \mathrm{D}^{+} \mathrm{B}$ cells were sorted by flow cytometry. RNA was extracted to determine the levels of transcription of $m h c l l, c d 83$, and cd80/86 (C) by real time PCR. Gene expression data were normalized against the endogenous control $b$-actin and are shown as relative expression (mean $+\mathrm{SEM} ; n=10)$. Asterisks denote significant differences between samples treated with rIFNs and control samples $\left({ }^{*} P \leq 0.05\right.$ and $\left.{ }^{\star *} P \leq 0.01\right)$.

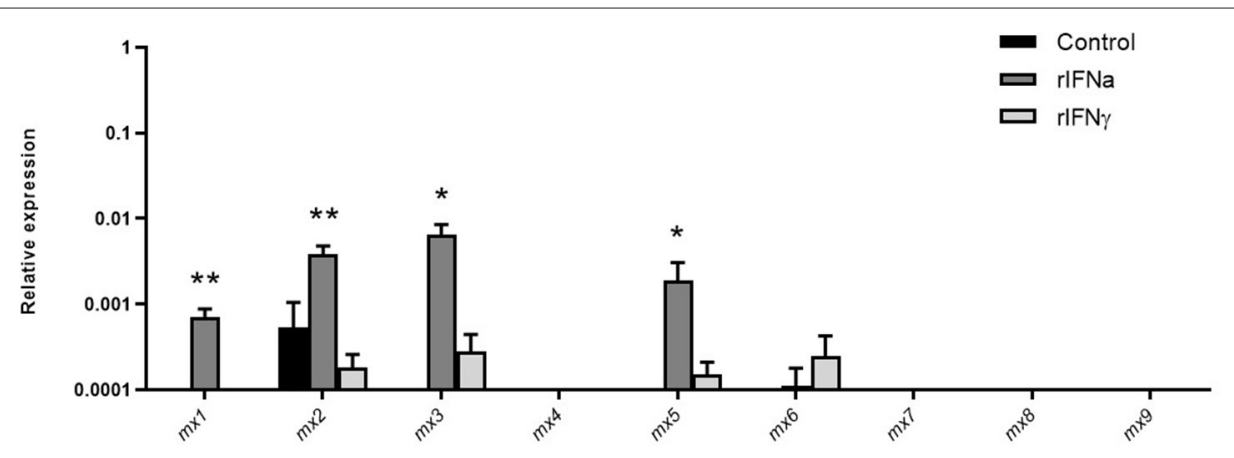

FIGURE 7 | Induction of $m x$ transcription in blood $\operatorname{lgM}{ }^{+} \lg D^{+}$B cells in response to type I or type II IFNs. Blood leukocytes were incubated with $50 \mathrm{ng} / \mathrm{ml} \mathrm{rlFNa}$, $20 \mathrm{ng} / \mathrm{ml} \mathrm{rlFN} \gamma$ or media alone (control) at $20^{\circ} \mathrm{C}$. After $24 \mathrm{~h}$, $\operatorname{lgM}^{+} \lg \mathrm{D}^{+} \mathrm{B}$ cells were sorted by flow cytometry and RNA extracted to determine the levels of transcription of the different $m x$ genes present in rainbow trout $(m \times 1-m \times 9)$. Gene expression data were normalized against the endogenous control $b$-actin and are shown as relative expression (mean $+\mathrm{SEM} ; n=10$ ). Asterisks denote significant differences between samples treated with rIFNs and control samples $\left({ }^{*} P \leq 0.05\right.$ and $\left.{ }^{\star \star} P \leq 0.01\right)$.

a direct effect of the cytokine. This increase in the number of $\mathrm{B}$ cells in PBL cultures was not consequence of IFNainduced lymphoproliferative effects as established through in vitro proliferation assays. In mammals, type I IFN rescues B cells from Fas induced spontaneous apoptosis through a mechanism involving phosphorylation of AKT and up-regulation of prosurvival molecules $(14,15)$. Hence, we investigated whether this could be the origin of the increased B cell survival in blood leukocyte cultures. Our results demonstrated that IFNa provoked a significant down-regulation of B cell spontaneous apoptosis, suggesting a similar mechanism to that reported in mammals. rIFN $\gamma$, on the other hand, only increased slightly the absolute number of $\mathrm{IgM}^{+} \mathrm{IgD}^{+} \mathrm{B}$ cells in the cultures, but had no effect on the percentage of $\operatorname{IgM}^{+} \operatorname{IgD}^{+} \mathrm{B}$ cells. Similarly, there was no effect of rIFN $\gamma$ when cells were sorted and then incubated with the cytokine, nor on B cell apoptosis. Therefore, $\operatorname{rIFN} \gamma$ may be exerting some minor effects on B cell viability through indirect mechanisms, but at levels much lower than those described here for rIFNa. In contrast, rIFN $\gamma$ had significant effects on the phagocytic capacity and the levels of surface MHC II expression of $\mathrm{IgM}^{-} \mathrm{IgD}^{-}$leukocytes present in the cultures.

In mammals, type I IFN acts as an amplifier of BCR signaling during viral infections, by taking the $\mathrm{B}$ cells to a state of partial activation in which cells have a higher sensitivity to further stimulation through the BCR (14). Thus, type I IFN significantly enhances responses to BCR ligation that include proliferation, calcium flux, IgM internalization and induction of activation markers (14). In rainbow trout, however, rIFNa did not synergize with BCR signaling to induce proliferation. The reason for this different response of trout $B$ cells could be linked to the fact that fish $\mathrm{B}$ cells do not proliferate in response to $\mathrm{BCR}$ ligation alone, unlike mammalian conventional
B2 cells but similar to mammalian B1 cells (43). In fact, there are many other functional and phenotypical similarities between fish B cells and mammalian innate B1 cells that include a strong phagocytic capacity, longer survival in cell culture, low IgD surface expression or expression of B1-specific markers (43). Interestingly, trout rIFNa was shown to up-regulate one of these innate features of fish B cells, their phagocytic activity, significantly increasing the number of phagocytic B cells in the cultures and the percentage of $B$ cells with a higher number of phagocytized beads. In this context, it would be interesting to investigate in mammals the effects of type I IFN in mammalian B1 cells, and determine for example, whether type I IFN also induces the phagocytic capacity of these cells as established for fish B cells.

Mammalian type I IFN has been repeatedly reported to increase antibody responses in vivo $(61,62)$. In these experiments, the increased antibody titers were dependent on $B$ cells being able to directly respond to $\operatorname{IFN} \alpha / \beta$ (61, 62), demonstrating a direct effect of type I IFN on B cell differentiation. To investigate if rIFNs on their own were capable of inducing the differentiation of fish naïve $B$ cells, we determined the number of IgM-secreting cells in blood leukocyte cultures after $72 \mathrm{~h}$ of exposure. In this case, both rIFNa and rIFN $\gamma$ significantly increased the number of plasmablasts/plasma cells in the cultures, although as observed throughout all the experiments, the effects of type I IFN were significantly higher than those of type II IFN. It might be possible that this increase in the number of IgM-secreting cells is a consequence of a general increased survival of B cells in the cultures, however, in agreement with our results, Atlantic salmon IFNa has been shown to be a potent molecular adjuvant for a DNA vaccine against infectious salmon anemia virus (ISAV), significantly 
increasing specific IgM titers to the vaccine (63). Furthermore, when a transcriptomic analysis of the local response to this plasmid coding for IFNa was undertaken in Atlantic salmon, $\operatorname{IgM}, \operatorname{IgD}$, and $\operatorname{IgT}$ were among the genes that were strongly up-regulated (64).

Mx genes are present in almost all vertebrates, usually as one to three copies. In mammals, these multiple copies are generally closely related and have arisen from local gene duplications (65). However, possibly as a consequence of the third teleostspecific WGD and a later salmonid-specific WGD, the Mx gene family, as with many other gene families, has undergone extensive diversification, with 6-10 different genes identified in salmonids $(48,59)$. In rainbow trout, the $9 \mathrm{Mx}$ genes present were constitutively transcribed by RTS11 macrophages, and among them, Mx1-7 were strongly induced by IFNa while only Mx5 and Mx6 increased their mRNA levels in response to IFN $\gamma$ (48). Similarly, in Atlantic salmon, $m x$ genes showed a differential responsiveness to type I and II IFNs, with those on Chr12 being highly induced by type I IFNs and those on Chr25 being more strongly induced by IFN $\gamma$ than by type I IFN $(48,59)$. However, to our knowledge, which $m x$ genes are expressed in B cells had never been addressed in teleost fish. Our results suggest that Mx4, Mx7, $\mathrm{Mx} 8$, and $\mathrm{Mx} 9$ are not produced by blood B cells, while Mx1, $\mathrm{Mx} 2, \mathrm{Mx} 3$, and $\mathrm{Mx} 5$ were strongly up-regulated in response to rIFNa (but not IFN $\gamma$ ). Whether this induction of $\mathrm{Mx}$ expression within B cells limits the capacity of viruses to replicate within these cells is something that should be investigated further, given that a direct antiviral activity has not yet been demonstrated for trout Mx proteins.

In conclusion, we report a previously undescribed role for teleost type I IFN in the regulation of $\mathrm{B}$ cell responses. Our results demonstrate that, as occurs in mammals, IFNa increased the survival of naïve $B$ cells by rescuing them from spontaneous apoptosis and increased IgM secretion. However, unlike mammalian B2 cells, fish B cells treated with type I IFN did not have an increased responsiveness to BCR stimulation. A possible explanation for this different response might be linked to the fact that fish $\mathrm{B}$ cells react differently to BCR stimulation than mammalian conventional B cells. Furthermore, given that fish B cells actually retain some innate functions such as a strong phagocytic capacity, we have also established that type I IFN regulates this activity in fish $B$ cells. Finally, the fact that several $m x$ genes are induced within B cells as a response to rIFNa points to an effect limiting the capacity of viruses to replicate within

\section{REFERENCES}

1. Manry J, Laval G, Patin E, Fornarino S, Itan Y, Fumagalli M, et al. Evolutionary genetic dissection of human interferons. J Exp Med. (2011) 208:2747-59. doi: $10.1084 /$ jem. 20111680

2. Samuel CE. Antiviral actions of interferons. Clin Microbiol Rev. (2001) 14:778-809. doi: 10.1128/CMR.14.4.778-809.2001

3. Lee AJ, Ashkar AA. The dual nature of type I and type II interferons. Front Immunol. (2018) 9:2061. doi: 10.3389/fimmu.2018.02061

4. Pestka S, Krause CD, Walter MR. Interferons, interferon-like cytokines, and their receptors. Immunol Rev. (2004) 202:8-32. doi: 10.1111/j.0105-2896.2004.00204.x
B cells. Our results provide further evidence of the interplay between cytokines of the innate immune system and cells of the adaptive immune system, which is an essential factor in the regulation of the immune response.

\section{DATA AVAILABILITY STATEMENT}

The datasets generated for this study are available on request to the corresponding author.

\section{ETHICS STATEMENT}

The animal study was reviewed and approved by INIA Ethics Committee.

\section{AUTHOR CONTRIBUTIONS}

TW produced the recombinant IFNs. OB performed and analyzed all the experiments with help from IS and PD-R. EM provided support with all flow cytometry experiments and performed the cell sortings. CT conceived the work and designed the experiments with help from TW, CS, OB, and PD-R and wrote the main body of the paper with contributions from all other authors. All authors contributed to the article and approved the submitted version.

\section{FUNDING}

This work was supported by the European Research Council (ERC Consolidator Grant No. 2016725061 TEMUBLYM), by the Spanish Ministry of Science, Innovation and Universities (project AGL2017-85494-C2-1-R) and by the Comunidad de Madrid (Grant No. 2016-T1/BIO-1672).

\section{ACKNOWLEDGMENTS}

The authors want to thank Lucia Gonzalez and Diana Martin for technical support.

\section{SUPPLEMENTARY MATERIAL}

The Supplementary Material for this article can be found online at: https://www.frontiersin.org/articles/10.3389/fimmu. 2020.01494/full\#supplementary-material 
9. Steimle V, Siegrist CA, Mottet A, Lisowska-Grospierre B, Mach B. Regulation of MHC class II expression by interferon-gamma mediated by the transactivator gene CIITA. Science. (1994) 265:106-9. doi: $10.1126 /$ science. 8016643

10. Kang S, Brown HM, Hwang S. Direct antiviral mechanisms of interferongamma. Immune Netw. (2018) 18:e33. doi: 10.4110/in.2018.18.e33

11. Kotenko SV, Gallagher G, Baurin VV, Lewis-Antes A, Shen M, Shah NK, et al. IFN-lambdas mediate antiviral protection through a distinct class II cytokine receptor complex. Nat Immunol. (2003) 4:69-77. doi: 10.1038/ni875

12. O'brien TR, Prokunina-Olsson L, Donnelly RP. IFN-lambda4: the paradoxical new member of the interferon lambda family. J Interferon Cytokine Res. (2014) 34:829-38. doi: 10.1089/jir.2013.0136

13. Kiefer K, Oropallo MA, Cancro MP, Marshak-Rothstein A. Role of type I interferons in the activation of autoreactive B cells. Immunol Cell Biol. (2012) 90:498-504. doi: 10.1038/icb.2012.10

14. Braun D, Caramalho I, Demengeot J. IFN- $\alpha / \beta$ enhances BCR-dependent B cell responses. Int Immunol. (2002) 14:411-9. doi: 10.1093/intimm/14.4.411

15. Badr G, Saad H, Waly H, Hassan K, Abdel-Tawab H, Alhazza IM, et al. Type I interferon (IFN-alpha/beta) rescues B-lymphocytes from apoptosis via PI3Kdelta/Akt, Rho-A, NFkappaB and Bcl-2/Bcl(XL). Cell Immunol. (2010) 263:31-40. doi: 10.1016/j.cellimm.2010.02.012

16. Green NM, Laws A, Kiefer K, Busconi L, Kim YM, Brinkmann MM, et al. Murine B cell response to TLR7 ligands depends on an IFN-beta feedback loop. J Immunol. (2009) 183:1569-76. doi: 10.4049/jimmunol.0803899

17. Mitani Y, Takaoka A, Kim SH, Kato Y, Yokochi T, Tanaka N, et al. Cross talk of the interferon-alpha/beta signalling complex with gp130 for effective interleukin-6 signalling. Genes Cells. (2001) 6:631-40. doi: 10.1046/j.1365-2443.2001.00448.x

18. Le Bon A, Schiavoni G, D'agostino G, Gresser I, Belardelli F, Tough DF. Type $i$ interferons potently enhance humoral immunity and can promote isotype switching by stimulating dendritic cells in vivo. Immunity. (2001) 14:461-70. doi: 10.1016/S1074-7613(01)00126-1

19. Wolf AI, Mozdzanowska K, Quinn WJ. III, Metzgar M, Williams KL, Caton AJ, et al. Protective antiviral antibody responses in a mouse model of influenza virus infection require TACI. J Clin Invest. (2011) 121:3954-64. doi: 10.1172/JCI57362

20. Hua J, Kirou K, Lee C, Crow MK. Functional assay of type I interferon in systemic lupus erythematosus plasma and association with antiRNA binding protein autoantibodies. Arthritis Rheum. (2006) 54:1906-16. doi: $10.1002 /$ art.21890

21. Secombes CJ, Zou J. Evolution of interferons and interferon receptors. Front Immunol. (2017) 8:209. doi: 10.3389/fimmu.2017.00209

22. Redmond AK, Zou J, Secombes CJ, Macqueen DJ, Dooley H. Discovery of all three types in cartilaginous fishes enables phylogenetic resolution of the origins and evolution of interferons. Front Immunol. (2019) 10:1558. doi: 10.3389/fimmu.2019.01558

23. Zou J, Gorgoglione B, Taylor NG, Summathed T, Lee PT, Panigrahi A, et al. Salmonids have an extraordinary complex type I IFN system: characterization of the IFN locus in rainbow trout Oncorhynchus mykiss reveals two novel IFN subgroups. J Immunol. (2014) 193:2273-86. doi: 10.4049/jimmunol.13 01796

24. Zou J, Tafalla C, Truckle J, Secombes CJ. Identification of a second group of type I IFNs in fish sheds light on IFN evolution in vertebrates. J Immunol. (2007) 179:3859-71. doi: 10.4049/jimmunol.179.6.3859

25. Aggad D, Mazel M, Boudinot P, Mogensen KE, Hamming OJ, Hartmann R, et al. The two groups of zebrafish virus-induced interferons signal via distinct receptors with specific and shared chains. J Immunol. (2009) 183:3924-31. doi: 10.4049/jimmunol.0901495

26. Svingerud T, Solstad T, Sun B, Nyrud ML, Kileng O, Greiner-Tollersrud L, et al. Atlantic salmon type I IFN subtypes show differences in antiviral activity and cell-dependent expression: evidence for high IFNb/IFNcproducing cells in fish lymphoid tissues. J Immunol. (2012) 189:5912-23. doi: 10.4049/jimmunol.1201188

27. Purcell MK, Laing KJ, Woodson JC, Thorgaard GH, Hansen JD. Characterization of the interferon genes in homozygous rainbow trout reveals two novel genes, alternate splicing and differential regulation of duplicated genes. Fish Shellfish Immunol. (2009) 26:293-304. doi: $10.1016 /$ j.fsi.2008.11.012
28. Yabu T, Toda H, Shibasaki Y, Araki K, Yamashita M, Anzai H, et al. Antiviral protection mechanisms mediated by ginbuna crucian carp interferon gamma isoforms 1 and 2 through two distinct interferon gamma-receptors. J Biochem. (2011) 150:635-48. doi: 10.1093/jb/mvr108

29. Araki K, Takizawa F, Yamasaki M, Esumi M, Morimoto T, Ototake M, et al. Expression profiles of interferon gamma genes in response to immunostimulants and alloantigen in ginbuna crucian carp Carassius auratus langsdorfii. Fish. Sci. (2013) 79:213-20. doi: 10.1007/s12562-012-0590-5

30. Belmonte R, Wang T, Duncan GJ, Skaar I, Melida H, Bulone V, et al. Role of pathogen-derived cell wall carbohydrates and prostaglandin E2 in immune response and suppression of fish immunity by the oomycete Saprolegnia parasitica. Infect Immun. (2014) 82:4518-29. doi: 10.1128/IAI.02196-14

31. Wang T, Johansson P, Abos B, Holt A, Tafalla C, Jiang Y, et al. First indepth analysis of the novel Th2-type cytokines in salmonid fish reveals distinct patterns of expression and modulation but overlapping bioactivities. Oncotarget. (2016) 7:10917-46. doi: 10.18632/oncotarget.7295

32. Pereiro P, Figueras A, Novoa B. Insights into teleost interferongamma biology: an update. Fish Shellfish Immunol. (2019) 90:150-64. doi: 10.1016/j.fsi.2019.04.002

33. Granja AG, Tafalla C. Different $\operatorname{IgM}(+)$ B cell subpopulations residing within the peritoneal cavity of vaccinated rainbow trout are differently regulated by BAFF. Fish Shellfish Immunol. (2019) 85:9-17. doi: 10.1016/j.fsi.2017.10.003

34. Arpin C, de Bouteiller O, Razanajaona D, Fugier-Vivier I, Briere F, Banchereau J, et al. The normal counterpart of $\operatorname{IgD}$ myeloma cells in germinal center displays extensively mutated $\mathrm{IgVH}$ gene, Cmu-Cdelta switch, and lambda light chain expression. J Exp Med. (1998) 187:1169-78. doi: 10.1084/jem.187.8.1169

35. Chen $\mathrm{K}, \mathrm{Xu} \mathrm{W}$, Wilson $\mathrm{M}, \mathrm{He} \mathrm{B}$, Miller NW, Bengten E, et al. Immunoglobulin $\mathrm{D}$ enhances immune surveillance by activating antimicrobial, proinflammatory and B cell-stimulating programs in basophils. Nat Immunol. (2009) 10:889-98. doi: 10.1038/ni.1748

36. Koelsch K, Zheng NY, Zhang Q, Duty A, Helms C, Mathias MD, et al. Mature $\mathrm{B}$ cells class switched to $\mathrm{IgD}$ are autoreactive in healthy individuals. J Clin Invest. (2007) 117:1558-65. doi: 10.1172/JCI27628

37. Edholm ES, Bengten E, Stafford JL, Sahoo M, Taylor EB, Miller NW, et al. Identification of two IgD + B cell populations in channel catfish, Ictalurus punctatus. J Immunol. (2010) 185:4082-94. doi: 10.4049/jimmunol.1000631

38. Castro R, Bromage E, Abos B, Pignatelli J, Gonzalez Granja A, Luque $A$, et al. CCR7 is mainly expressed in teleost gills, where it defines an IgD+IgM- B lymphocyte subset. J Immunol. (2014) 192:1257-66. doi: 10.4049/jimmunol.1302471

39. Perdiguero P, Martin-Martin A, Benedicenti O, Diaz-Rosales P, Morel E, Munoz-Atienza E, et al. Teleost $\operatorname{IgD}(+) \operatorname{IgM}(-)$ B cells mount clonally expanded and mildly mutated intestinal $\operatorname{IgD}$ responses in the absence of lymphoid follicles. Cell Rep. (2019) 29:4223-35. doi: 10.1016/j.celrep.2019.11.101

40. Zhang YA, Salinas I, Li J, Parra D, Bjork S, Xu Z, et al. IgT, a primitive immunoglobulin class specialized in mucosal immunity. Nat Immunol. (2010) 11:827-35. doi: 10.1038/ni.1913

41. Xu Z, Takizawa F, Parra D, Gomez D, von Gersdorff Jorgensen L, LaPatra SE, et al. Mucosal immunoglobulins at respiratory surfaces mark an ancient association that predates the emergence of tetrapods. Nat Commun. (2016) 7:10728. doi: 10.1038/ncomms10728

42. Li J, Barreda DR, Zhang YA, Boshra H, Gelman AE, Lapatra S, et al. B lymphocytes from early vertebrates have potent phagocytic and microbicidal abilities. Nat Immunol. (2006) 7:1116-24. doi: 10.1038/nil389

43. Abos B, Bird S, Granja AG, Morel E, More Bayona JA, Barreda $\mathrm{DR}$, et al. Identification of the first teleost CD5 molecule: additional evidence on phenotypical and functional similarities between fish $\operatorname{IgM}(+)$ B cells and mammalian B1 cells. J Immunol. (2018) 201:465-80. doi: $10.4049 /$ jimmunol.1701546

44. Baumgarth $\mathrm{N}$. The double life of a B-1 cell: self-reactivity selects for protective effector functions. Nat Rev Immunol. (2011) 11:34-46. doi: 10.1038/nri2901

45. Tang X, Yang S, Sheng X, Xing J, Zhan W. Transcriptome analysis of immune response of $\operatorname{mIgM}(+)$ B lymphocytes in Japanese flounder (Paralichthys olivaceus) to Lactococcus lactis in vitro revealed that IFN I-3 could enhance their phagocytosis. Front Immunol. (2019) 10:1622. doi: 10.3389/fimmu.2019.01622 
46. Abos B, Castro R, Pignatelli J, Luque A, Gonzalez L, Tafalla C. Transcriptional heterogeneity of $\operatorname{IgM}^{+}$cells in rainbow trout (Oncorhynchus mykiss) tissues. PLoS ONE. (2013) 8:e82737. doi: 10.1371/journal.pone.0082737

47. Wang T, Huang W, Costa MM, Martin SA, Secombes CJ. Two copies of the genes encoding the subunits of putative interleukin (IL)-4/IL13 receptors, IL-4R $\alpha$, IL- $13 \mathrm{R} \alpha 1$ and IL-13R $\alpha 2$, have been identified in rainbow trout (Oncorhynchus mykiss) and have complex patterns of expression and modulation. Immunogenetics. (2011) 63:235-53. doi: 10.1007/s00251-010-0508-2

48. Wang T, Liu F, Tian G, Secombes CJ, Wang T. Lineage/species-specific expansion of the Mx gene family in teleosts: differential expression and modulation of nine Mx genes in rainbow trout Oncorhynchus mykiss. Fish Shellfish Immunol. (2019) 90:413-30. doi: 10.1016/j.fsi.2019.04.303

49. Wang T, Diaz-Rosales P, Costa MM, Campbell S, Snow M, Collet B, et al. Functional characterization of a nonmammalian IL-21: rainbow trout Oncorhynchus mykiss IL-21 upregulates the expression of the Th cell signature cytokines IFN-gamma, IL-10, and IL-22. J Immunol. (2011) 186:708-21. doi: 10.4049/jimmunol.1001203

50. Ganassin RC, Bols NC. Development of a monocyte/macrophage-like cell line, RTS11, from rianbow trout spleen. Fish Shellfish Immunol. (1998) 8:457-76. doi: 10.1006/fsim.1998.0153

51. Zou J, Carrington A, Collet B, Dijkstra JM, Yoshiura Y, Bols N, et al. Identification and bioactivities of IFN-gamma in rainbow trout Oncorhynchus mykiss: the first Th1-type cytokine characterized functionally in fish. $J$ Immunol. (2005) 175:2484-94. doi: 10.4049/jimmunol.175.4.2484

52. Deluca D, Wilson M, Warr GW. Lymphocyte heterogeneity in the trout, Salmo gairdneri, defined with monoclonal antibodies to IgM. Eur J Immunol. (1983) 13:546-51. doi: 10.1002/eji.1830130706

53. Ramirez-Gomez F, Greene W, Rego K, Hansen JD, Costa G, Kataria P, et al. Discovery and characterization of secretory IgD in rainbow trout: secretory IgD is produced through a novel splicing mechanism. J Immunol. (2012) 188:1341-9. doi: 10.4049/jimmunol.1101938

54. Granja AG, Leal E, Pignatelli J, Castro R, Abos B, Kato G, et al. Identification of teleost skin CD8alpha+ dendritic-like cells, representing a potential common ancestor for mammalian cross-presenting dendritic cells. J Immunol. (2015) 195:1825-37. doi: 10.4049/jimmunol.1500322

55. Simon R, Diaz-Rosales P, Morel E, Martin D, Granja AG, Tafalla C. $\mathrm{CpG}$ oligodeoxynucleotides modulate innate and adaptive functions of $\operatorname{IgM}(+)$ B cells in rainbow trout. Front Immunol. (2019) 10:584. doi: 10.3389/fimmu.2019.00584

56. Schoenborn JR, Wilson CB. Regulation of interferon-gamma during innate and adaptive immune responses. Adv Immunol. (2007) 96:41-101. doi: 10.1016/S0065-27760796002-2
57. Staeheli P, Pitossi F, Pavlovic J. Mx proteins: GTPases with antiviral activity. Trends Cell Biol. (1993) 3:268-72. doi: 10.1016/0962-89249390055-6

58. Holzinger D, Jorns C, Stertz S, Boisson-Dupuis S, Thimme R, Weidmann $\mathrm{M}$, et al. Induction of $\mathrm{MxA}$ gene expression by influenza $\mathrm{A}$ virus requires type I or type III interferon signaling. J Virol. (2007) 81:7776-85. doi: 10.1128/JVI.00546-06

59. Robertsen B, Greiner-Tollersrud L, Jorgensen LG. Analysis of the Atlantic salmon genome reveals a cluster of $\mathrm{Mx}$ genes that respond more strongly to IFN gamma than to type I IFN. Dev Comp Immunol. (2019) 90:80-9. doi: 10.1016/j.dci.2018.09.004

60. Muller U, Steinhoff U, Reis LF, Hemmi S, Pavlovic J, Zinkernagel RM, et al. Functional role of type I and type II interferons in antiviral defense. Science. (1994) 264:1918-21. doi: 10.1126/science.8009221

61. Fink K, Lang KS, Manjarrez-Orduno N, Junt T, Senn BM, Holdener $\mathrm{M}$, et al. Early type I interferon-mediated signals on B cells specifically enhance antiviral humoral responses. Eur J Immunol. (2006) 36:2094-105. doi: 10.1002/eji.200635993

62. Le Bon A, Thompson C, Kamphuis E, Durand V, Rossmann C, Kalinke $\mathrm{U}$, et al. Cutting edge: enhancement of antibody responses through direct stimulation of B and T cells by type I IFN. J Immunol. (2006) 176:2074-8. doi: 10.4049/jimmunol.176.4.2074

63. Chang CJ, Sun B, Robertsen B. Adjuvant activity of fish type I interferon shown in a virus DNA vaccination model. Vaccine. (2015) 33:2442-8. doi: 10.1016/j.vaccine.2015.03.093

64. Sobhkhez M, Krasnov A, Chang CJ, Robertsen B. Transcriptome analysis of plasmid-induced genes sheds light on the role of type I IFN as adjuvant in DNA vaccine against infectious salmon anemia virus. PLoS ONE. (2017) 12:e0188456. doi: 10.1371/journal.pone.0188456

65. Verhelst J, Hulpiau P, Saelens X. Mx proteins: antiviral gatekeepers that restrain the uninvited. Microbiol Mol Biol Rev. (2013) 77:551-66. doi: 10.1128/MMBR.00024-13

Conflict of Interest: The authors declare that the research was conducted in the absence of any commercial or financial relationships that could be construed as a potential conflict of interest.

Copyright (C) 2020 Benedicenti, Wang, Morel, Secombes, Soleto, Díaz-Rosales and Tafalla. This is an open-access article distributed under the terms of the Creative Commons Attribution License (CC BY). The use, distribution or reproduction in other forums is permitted, provided the original author(s) and the copyright owner(s) are credited and that the original publication in this journal is cited, in accordance with accepted academic practice. No use, distribution or reproduction is permitted which does not comply with these terms. 